\title{
Local Resident Attitudes to the Sustainable Development of Urban Public Transport System
}

\author{
Roman Roaljdovich Sidorchuk*, Anastasia Vladimirovna Lukina, Sergey Vladimirovich Mkhitaryan, \\ Irina Ivanovna Skorobogatykh and Anastasia Alexeevna Stukalova
}

check for updates

Citation: Sidorchuk, R.R.; Lukina, A.V.; Mkhitaryan, S.V.;

Skorobogatykh, I.I.; Stukalova, A.A. Local Resident Attitudes to the Sustainable Development of Urban Public Transport System. Sustainability 2021, 13, 12391. https://doi.org/10.3390/su132212391

Academic Editors: Efthimios Bothos, Panagiotis Georgakis,

Babis Magoutas and Michiel de Bok

Received: 7 October 2021

Accepted: 8 November 2021

Published: 10 November 2021

Publisher's Note: MDPI stays neutral with regard to jurisdictional claims in published maps and institutional affiliations.

Copyright: (c) 2021 by the authors. Licensee MDPI, Basel, Switzerland. This article is an open access article distributed under the terms and conditions of the Creative Commons Attribution (CC BY) license (https:// creativecommons.org/licenses/by/ $4.0 /)$.
Department of Marketing, Plekhanov Russian University of Economics, 117997 Moscow, Russia; anastacialukina@bk.ru (A.V.L.); serezha.mkhitaryan@inbox.ru (S.V.M.); irasckorobogatyh@yandex.ru (I.I.S.); anastasiastukalova@list.ru (A.A.S.)

* Correspondence: professor_sidorchuk@mail.ru

Abstract: This article presents a study of the attitude of metropolis residents to the environmental development of the urban public transport system. The authors set a goal to assess the influence of values on the assessment of environmental initiatives of city authorities in the field of public transport and their attitude to innovations in this sphere. In the course of the study, four clusters reflecting the values of the respondents were identified. The results showed support for innovations that do not require changes in the transport behavior of the individual. At the same time, we observe differences in the perception of initiatives by representatives of different clusters when the innovation affects their transportation behavior. Hypotheses were tested as an analysis result of empirical data by determining the synthetic indices of values using factor analysis, the classification of respondents based on the obtained indices to identify groups with similar values using cluster analysis, and an analysis of the relationship of the classification results by values using contingency tables and chi-square criterion. The scientific novelty of the study is to assess the impact of values of metropolis residents on the perception of environmental conditions and their change in the city.

Keywords: human values; sustainability; public transport; sustainable development; marketing

\section{Introduction}

Public transport is an important factor in metropolises' social and economic development [1]. At the same time, the growing number of vehicles in a city is becoming the main source of pollution. On the one hand, the need for mobility increases, and on the other hand, the environmental pressure from the metropolis transport system increases, forming incentives for innovation in sustainable transport. Many cities are implementing smart city systems and other innovations that help increase the efficiency of the urban transport system and reduce the level of environmental pollution.

At the same time, the innovations introduced are not always easily perceived and accepted by the users of the urban transport system. Many of the innovations require a change in the behavior of individuals, which often meets with internal protest, causes resistance, and dissatisfaction in society [2,3].

In this regard, the study of residents' attitudes towards innovations for sustainable development of the metropolitan transport network becomes particularly relevant. The term "attitude" is used as a universal term to conceptualize the beliefs, values, perceptions, knowledge, awareness, opinions, and fears of individuals, especially when it is necessary to study the perception of environmental problems and risks in the context of travel behavior including travel on all modes of transport as well as car purchasing decisions and driving behaviors [4]. In this regard, it is important to understand not only residents' perception of transport innovations in the metropolis for sustainable development, but also their perception of the environmental situation in the city, and to what extent this perception reflects the real environmental situation and changes in the city. Such knowledge is 
extremely important because management decisions on the development of the metropolis transport network are based on indicators that reflect the objective state of the city's environment. We were interested to understand to what extent the objective indicators of the city environment quality and the perception of the environment by the citizens are consistent with each other.

In this context, the role of marketing activities in public transport is increasing, which should focus on the rational use of public goods, such as public spaces, air, water, and the like for sustainable development, and primarily through open innovation [5]. The marketing task is to help city governments select the impact and regulatory tools to adapt the residents and other actors to changes [6].

Thus, there is a need for studies capable of identifying and analyzing problems and seeking innovative solutions to existing urban public transportation problems [7]. The basis for finding these kinds of solutions should be the study of residents' attitudes towards the environmental development of the urban public transport system.

Therefore, the goals of this study were to:

- Identify passenger segments using cluster analysis based on high-level values (HLV);

- Identify the attitude to the actions of the city authorities aimed at improving the environmental situation in the urban transport system;

- Reveal residents' attitude towards joint responsibility with the city authorities for the environmental situation in the city;

- Assess the perception of the environmental situation in the city and its true state in terms of emissions from urban transport.

Based on the above goals, the following hypotheses were developed:

Hypothesis 1 (H1). Attitudes towards the actions of the city authorities aimed at improving the environmental situation by changing the transport system will differ among residents with different values.

Hypothesis 2 (H2). Residents are aware of their responsibility for the environmental situation in the city due to the development of the urban transportation system.

Hypothesis 3 (H3). Residents' subjective perception of the environmental situation may not correspond to the objective environmental situation in the city.

The rest of the paper is organized as follows. First, Section 2 analyzes the literature and describes the current state of the problem under study. Then, in Section 3, the research methodology is presented. The main results are presented in Section 4. After this, the obtained results are discussed in Section 5. Finally, Section 6 provides conclusions, limitations, and prospects for further research, concluding the article.

\section{Literature Review}

Modern urban planning increasingly emphasizes comprehensive benefits for the planning goals of the economy, society, and environment based on ecological infrastructure [8-13]. In the last decade, the field of transport and mobility, as a whole, has undergone significant changes [14-19], as there is a close link between it and the general economic development [20-22]. This link becomes especially tangible in cities, where a large proportion of the population is concentrated [23-25] and negative environmental impacts are also the most tangible [26-31]. These are often the result of heavy traffic [32].

Largely, solutions of these problems are related to innovation of both the use of vehicles and infrastructure. Those could be, for example, the development of personal mobility devices [33] or the system for the use of parking [34,35] or modeling their need [36].

At the same time, most researchers agree that implementing innovations within the concept of a smart city is impossible without the population's participation, which is expressed as opinions, assessments, and suggestions [37-44]. In examining the determinant 
factors affecting urban development, Myeong suggested that smart city development includes citizen participation with multi-communication channels in building a smart city. These experts said that smart cities could not move in the right direction without citizen participation [45-48]. Among the many factors considered, population engagement came out on top.

An important role in modern urban planning is considering population attitude and perception assessments into transportation management decisions, sustainable urban development, and urban environmental transformation [49-52], largely due to the increasing demand for innovative transportation policies to address congestion, air pollution, and greenhouse gas emissions [53-55].

A striking example of public participation in the life of a city is online voting platforms. The practice of taking account of the population's opinion on certain issues through specialized websites and mobile applications is widespread not only in metropolises but also in towns. It should be taken into account that some of the first topics for voting were exactly the issues of transport planning and air pollution regulation through the introduction of transport restrictions. To date, it can be stated that these issues remain very relevant and attract as many participants as the distribution of the city budget.

In reality, the population's attitude towards air pollution, congestion traffic, and lack of accessibility of the public transport for the suburbs was at the basis of the creation of the new order in cities $[56,57]$ and the formation of sustainable urban mobility plans. Citizens play an important role in all the stages of sustainable transport developmentdiagnosing the current situation, identifying solutions, devising development plans, and implementing them $[20,58,59]$. The development of the city, taking into account modern environmental requirements and any ecosystem management process, is not possible without understanding the values of each stakeholder [46,60,61].

In Russian metropolises, the situation of residents being passive to the problems of transport ecology had developed historically. Residents consider information about the state of the environment not as an incentive to change their behavior but as spectatorship and evaluation of the authorities' actions to improve the population's quality of life [62]. The leading role in aforementioned initiatives belonged to the federal and regional authorities. In this regard, it would be important to understand how much residents are aware of their responsibility for the environmental situation in the city as a result of the development of the urban transportation system and how subjective perception of the environmental situation corresponds to the objective environmental situation in the city. This circumstance determines effective measures and policies that change people's mobility towards desired sustainable mobility. Individual mobility needs and mobility determinants must be considered to understand how different people respond to measures and policies and increase their effectiveness [63]. Attitudes and values become key aspects when considering this issue. As follows form studies in the literature: "Based on the surveys implemented in six Asian countries, i.e., Japan, Thailand, China, Vietnam, Indonesia, and the Philippines, the factor analysis of 31 beliefs revealed three factors underlying the attitudes toward cars and public transport, namely Symbolic affective, Instrumental and Social orderliness" [64,65]. Other works have also investigated various factors determining the influence on policy choices aimed at reducing greenhouse gas emissions from transport, where the role of particular attitudinal indicators based, for example, on the theory of interpersonal behavior, the theory of planned behavior, goal-oriented behavior model, Schwarz model [66] was noted.

At the same time, the authors in their studies have covered only certain aspects of attitudes that can characterize human values. The concept of human value is different from attitude [67] and can be based on different approaches [68-70].

In this regard, it becomes important to understand how attitudes towards the actions of the city authorities aimed at improving the environmental situation by changing the transportation system will differ among residents with different values. Such an approach is 
due to a gap in the literature regarding considering residents' attitudes based on clustering depending on their values, for example, using Schwartz's theory of values.

Thus, scientists have resorted to various ways of clustering the population to study the public's opinion to make management decisions on transportation planning and environmental issues within the urban environment [71,72]. For example, the literature considers an approach based on cluster analysis of latent classes, which identified three segments: hared-mode enthusiast, shared-mode opponent, and fixed-route transit loyalist [73].

Traditionally, segmentation based on demographic variables and individual behavioral characteristics has been used to study the behavioral characteristics of particular groups [74]. Using this approach to study composite complex behavior within large groups can lead to the oversimplification of the resulting model.

One of the first studies of opinions and attitudes of people about urban transport, based on the survey, in Poland and for countries in Central and Eastern Europe, is based on the principle of dividing the population by age, focusing on the mobility choices of young adults (more specifically, Generation Y) [75].

Particular attention should be paid to studies in which the evaluation of the population on the prospects of environmental changes related to transport is made based on the division of respondents according to their level of involvement in an issue. However, experts preferred techno-economic measures while the public prioritized behavioral change and public transport improvement [76,77]. Thus, cluster analysis seems to us to be a higher priority for studies of the values of the population in the area in question.

Weiand, studying the connection between traffic intervention policies and public acceptance in a local context [78] amid climate change and air pollution, uses agglomerative hierarchical clustering and multiple correspondence analyses. Based on hierarchical cluster analysis, the researchers identified four clusters: "unconcerned car-dependent policy-rejectors", "multimodal policy-skeptics", "green-travel policy-optimists" and "bikededicated policy-enthusiasts".

Notably, hierarchical and partitioning cluster analyses are most commonly used for transportation research $[79,80]$. Magdolen, to utilize the advantage of both methodologies, in his study uses a combination of Ward's hierarchical method with the partitioning method of k-means in a two-step cluster analysis. The study resulted in the identification of eight clusters. Each cluster represents a mobility style with distinctive characteristics reflecting a group of people [63].

Separately, it should be noted that the process of involving motorists in the use of public transport services is not losing its relevance [81]. This vector of urban development makes it necessary to improve knowledge about the perception of public transport by motorists. For this reason, there is a significant amount of research devoted to the study of service quality, satisfaction, and behavioral intentions towards public transport from the point of view of private vehicle users [82]. In such cases, the first stage of the study is selecting and separating respondents according to the fact of using public or private transportation $[83,84]$. As part of the study of this direction, de Oña uses confirmatory factor analysis to identify the most important service quality attributes for the car users; structural equation modeling for investigating the relationships among the three factors; and multi-group analysis and a multiple-indicator and multiple-causes approach to identify heterogeneity in the models because of geographical context or socio-demographic characteristics $[81,84]$.

Thus, we can conclude that the values of citizens in the framework of their assessment of management decisions on transport and environmental transformations of the city remain understudied, as well as the differences in the attitude and perception of urban policy in greening the transport system as a whole.

Today, urban transportation systems face the challenges of developing sustainable transportation policies aimed at greening transportation [85-87]. However, the effectiveness of solutions to achieve these objectives depends largely on public attitudes. At the same time, a significant influence of the mass media on this process should be noted $[4,88]$. 
Despite clear public demands for urban environmental improvements, not all management decisions resonate with the population.

One possible reason may be related to the differences in the subjective perception of residents of the environmental situation and its objective state. The literature notes that subjective experience can be as important as objective indicators [89]. At the same time, for public transport, these kinds of issues are considered mainly in terms of the perceived quality of transport services [90], rather than looking for differences in the subjective perception of the transport impact on the environment and the objective situation.

In conclusion of the literature review, it should be noted that methods combining qualitative and quantitative research using cluster analysis are applied to identify key factors of public attitudes towards sustainable transport policy. However, this topic remains understudied to form the basis for managerial decision-making in greening territories, cities, and metropolises.

The literature mostly presents the results of studies, whose objectives were to assess the attitude to the already taken decisions in the management of the transport complex, or the clustering did not simultaneously take into account aspects of public satisfaction with the urban transport system, including the aspects of the impact on the environment of the region. Also, the implementation results of the recommendations formulated based on analysis in a time perspective are poorly presented.

\section{Methodology}

Hypothesis testing took place in three stages. It was necessary to identify clusters of individuals (metropolitan residents) with similar basic values at the first stage.

In order to test the hypothesis, 40 projection questions describing basic human HLVs were added to the questionnaire (Table 1). For each question, four alternative answers were offered:

1. Not like me;

2. A little bit like me;

3. Looks like me;

4. Very much like me.

Table 1. Questions on values (basic human values).

\begin{tabular}{|c|c|}
\hline Question on the Basic Value & Basic Value \\
\hline 1. He/she likes to do things his way, do something new and be inventive & Independence \\
\hline 2. He/she tends to be rich and have expensive things & Power \\
\hline 3. He/she believes that everyone should have equal rights and opportunities in life & Universalism \\
\hline $\begin{array}{l}\text { 4. It is important for him/her to show his/her abilities and talents. He/she wants people to admire } \\
\text { what he/she does }\end{array}$ & Achievement \\
\hline $\begin{array}{l}\text { 5. It is important for him/her to live in a safe environment. He/she avoids anything that might } \\
\text { threaten his/her safety }\end{array}$ & Safety \\
\hline $\begin{array}{l}\text { 6. He/she always strives for novelty and believes that it is important to do many different things } \\
\text { in life }\end{array}$ & Stimulation \\
\hline 7. He/she believes that people should adhere to the established rules, even when no one sees them & Conformity \\
\hline $\begin{array}{l}\text { 8. It is important for him/her to listen to people's opinions that differ from his/her perspective. Even } \\
\text { if he/she disagrees, he/she still tries to understand them }\end{array}$ & Conformity \\
\hline $\begin{array}{l}\text { 9. He/she believes that people should be happy with what they have at the moment and not ask for } \\
\text { more from others }\end{array}$ & Traditionalism \\
\hline $\begin{array}{l}\text { 10. He/she is always looking for a reason to have fun. It is important for him/her to do things that } \\
\text { give him/her pleasure }\end{array}$ & Hedonism \\
\hline $\begin{array}{l}\text { 11. It is important for him/her to decide for himself/herself what to do. He/she likes to make } \\
\text { his/her own decisions in planning and choosing his/her activities }\end{array}$ & Independence \\
\hline
\end{tabular}


Table 1. Cont.

\begin{tabular}{|c|c|}
\hline Question on the Basic Value & Basic Value \\
\hline $\begin{array}{l}\text { 12. It is important for him/her to benefit those around him/her and take care of their well-being. He } \\
\text { tries to support those close to him/her }\end{array}$ & Benevolence \\
\hline $\begin{array}{l}\text { 13. It is important for him/her to succeed and be an orientation target for other people. He likes to } \\
\text { impress them }\end{array}$ & Achievement \\
\hline $\begin{array}{l}\text { 14. The security of the country is very important to him/her. He/she believes that the state must be } \\
\text { ready to defend itself against external and internal threats }\end{array}$ & Safety \\
\hline 15. He/she likes to take risks and seeks adventures & Stimulation \\
\hline $\begin{array}{l}\text { 16. It is important for him/her to behave properly. He/she tries to avoid doing things that people } \\
\text { would consider wrong }\end{array}$ & Conformity \\
\hline 17. It is important for him/her to be a leader and tell others what to do & Power \\
\hline 18. It is important for him/her to be loyal to his/her friends & Benevolence \\
\hline $\begin{array}{l}\text { 19. He/she is convinced that people should take care of nature. It is important for him/her to take } \\
\text { care of the environment }\end{array}$ & Universalism \\
\hline 20. Religion is important to him/her in life. He/she strives to follow his/her religious beliefs & Traditionalism \\
\hline 21. He/she does not like disorders. It is important to him/her to keep things clean and tidy & Safety \\
\hline $\begin{array}{l}\text { 22. He/she believes that it is important to be a versatile person and be interested in many things. } \\
\mathrm{He} / \text { she likes to be inquisitive }\end{array}$ & Independence \\
\hline $\begin{array}{l}\text { 23. He/she believes that all people of the world should live in harmony. It is important to him/her to } \\
\text { promote peace among all groups of people in the world }\end{array}$ & Universality \\
\hline $\begin{array}{l}\text { 24. He/she believes it is important to be ambitious in life, to strive to achieve success according to } \\
\text { his/her personal goals. He/she wants to demonstrate how capable he/she is }\end{array}$ & Achievement \\
\hline $\begin{array}{l}\text { 25. He/she believes that he/she should act according to established traditions. It is important for } \\
\text { him/her to observe the customs he/she has learned in life }\end{array}$ & Traditionalism \\
\hline 26. He/she likes not to deny himself/herself anything and enjoy life & Hedonism \\
\hline $\begin{array}{l}\text { 27. It is important for him/her to be sensitive to the needs of others. He/she tries to support those } \\
\text { he/she knows }\end{array}$ & Benevolence \\
\hline $\begin{array}{l}\text { 28. He/she believes that he/she should always show respect for parents and elders and attend } \\
\text { to them }\end{array}$ & Conformity \\
\hline $29 \mathrm{He} /$ she wants everyone to be treated fairly. It is important to him/her to protect the weak & Universalism \\
\hline $\begin{array}{l}\text { 30. He/she loves surprises. It is important to him/her that his/her life should be full of bright } \\
\text { impressions }\end{array}$ & Stimulation \\
\hline
\end{tabular}

31. It is important to be healthy for him/her

Safety

32. It is important for him/her to develop and advance constantly. He/she strives to do everything better than others

Achievement

33. He/she tries to see only good in people. He/she believes he/she must be prepared to forgive and have no resentment against other people who have offended him/her

34. It is important for him/her to be independent. He/she likes to rely on his/her own strength

Benevolence

35. Stability in the state is important for him/her

Independence

36. It is important for him/her to be courteous to other people. He/she tries not to annoy or disturb others

Safety

37. He/she is a swinger and likes to spend his/her free time well

Conformity

38. It is important for him/her to be modest. He/she tries not to draw attention to himself/herself

Hedonism

39. It is important for him/her to acquire authority, to have an influence on others

Conformity

Power

40. It is important for him/her to be in harmony with nature, to be part of it. He/she believes that people should not change nature too much

Universalism 
In order to analyze the reliability of the results obtained, a test was conducted using Cronbach's coefficient $\alpha$. Cronbach's alpha was used to assess the scale's internal consistency.

Based on descriptive statistics (averages), most and least similar personality types to most respondents were identified.

The average conformity assessment of the values to the respondent:

1. Fully do not conform;

2. Do not conform;

3. Conform;

4. Fully conform.

For a deeper study of the survey results, factor (component) analysis was used to determine the synthetic indices of values. The indices obtained were supposed to classify respondents using cluster analysis to identify groups with similar values. Data suitability for factor analysis was checked using the Kaiser-Meyer-Olkin test (KMO test). A Varimax rotation was used to interpret the indices.

Next, we analyzed the socio-demographic characteristics of respondents for each cluster. Construction of clusters' socio-demographic profile is necessary to understand how respondents were distributed into clusters and who forms each cluster.

At the second stage, Hypotheses 1 and 2 were tested. We studied the differences in the attitude towards the actions of the city authorities aimed at improving the environmental situation by changing the transport system (H1) and the residents' awareness of their responsibility for the environmental situation in the city as a result of the development of the urban transport system (H2).

The third stage involved the analysis of statistical data on changes in key indicators of the environment in the city in the dynamics over five years (from 2016 to 2020) and a comparison of the perception of the environmental situation in the city and its real state (H3).

The study of the perception of environmental innovations on the development of urban public transport in Moscow was conducted with the help of an online survey of the capital's residents in early March 2020. Quota sampling was used proportional to the gender and age composition for each of the administrative districts of Moscow to ensure representativeness. As a result, 969 men (43\%) and 1306 (57\%) women were questioned, 2275 respondents in total. Due to using the introductory part of the questionnaire with screening questions, people under 18 did not participate in the further survey. Such respondents were $0.56 \%$ of those who started to fill out the questionnaire (not included in the quotas). The share of respondents by age and gender was also controlled to ensure that the sampling was representative according to the structure of the Moscow population according to these parameters.

In this study, the data array was analyzed using the IBM SPSS Statistics 20 software package.

The study used several methodological approaches:

- An online survey of city residents based on quota sampling proportional to gender and age composition for each of Moscow's administrative districts;

- The methodology of projective evaluation of human HLV is based on Schwartz's value theory and marketing approach [67,91-93].

- The methodology of descriptive statistics (averages) to determine the most and least similar personality types to the majority of respondents;

- Factor (component) analysis to determine synthetic indices of human HLV. Based on the indices obtained, respondents were classified using cluster analysis to identify groups with similar values;

- Model of the values' influence on the assessment of environmental initiatives of the city authorities in the field of public transport. Statistical forecasting methods described in the literature were used in the modeling [34,94]. 
- Dynamic analysis of changes in concentrations of major pollutants in Moscow is based on state statistics data, which allowed comparing the subjective perception of the city's environmental state with the objective one.

\section{Results}

\subsection{Stage 1: Clustering of Respondents Based on Basic Values}

Cronbach's alpha was used to assess the scale's internal consistency; its value was 0.927, indicating external consistency and internal consistency.

The following values were most relevant to the respondents:

No. 31-It is important to be healthy for him/her (Safety) - 3.38 points;

No. 22- $\mathrm{He} /$ she believes that it is important to be a versatile person and be interested in many things. He/she likes to be inquisitive (Independence)-3.22 points;

No. $28-\mathrm{He} / \mathrm{she}$ believes that he/she should always respect parents and elders and attend to them (Conformity) - 3.21 points.

The following values were least of all relevant to the respondents:

No. 2-He/she tends to be rich and have expensive things (Power) - 1.8 points;

No. 15-He/she likes to take risks and seeks adventures (Stimulation) - 8 points.

The importance of basic human values for the respondents was assessed based on the average scores according to Table 1 . As a result, the following diagram was obtained (Figure 1).

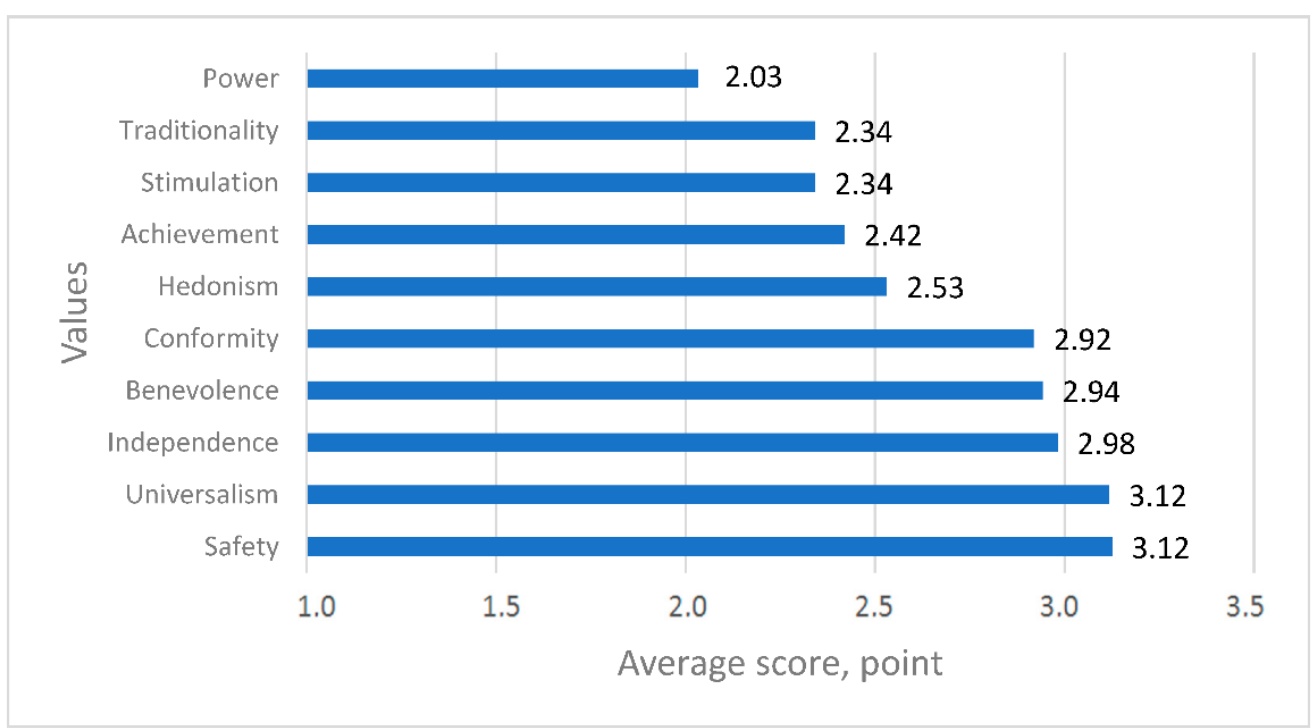

Figure 1. Average conformity scores with life values (1-Fully do not conform, 4-Fully conform).

Thus, the most significant values are Safety and Universalism (average score above 3.1); the most significant values are Independence, Benevolence, and Conformity (average score above 2.9, but less than 3); the least significant values are Power, Traditionalism, and Stimulation (average score below 2.4).

In order to determine the factors of values, it is necessary to previously consider a smaller number of synthetic variables (indices) instead of forty initial variables. For this purpose, a statistical dimensionality reduction tool was applied-factor analysis (method of principal components). The test result was 0.946, exceeding 0.9, indicating that the variables correlate sufficiently and are suitable for factor analysis.

As a result, 7 indices were obtained, of which eigenvalues, according to the Kaiser criterion, exceed 1 . They explain $56 \%$ of the variance of the original data. A Varimax rotation was used to interpret the indices. Explanatory variables and corresponding factor 
loadings, based on which the interpretation of the indices was carried out, are presented in Table 2.

Table 2. Results of factor analysis—-method of principal components.

\begin{tabular}{|c|c|}
\hline Initial Variables, Explaining Factors & Factor Loadings \\
\hline \multicolumn{2}{|l|}{ Factor 1} \\
\hline $\begin{array}{l}\text { 27. It is important for him/her to be sensitive to the needs of others. He/she tries to support those } \\
\text { he/she knows }\end{array}$ & 0.75 \\
\hline $\begin{array}{l}\text { 28. He/she believes that he/she should always show respect for parents and elders and attend } \\
\text { to them }\end{array}$ & 0.70 \\
\hline $29 \mathrm{He} /$ she wants everyone to be treated fairly. It is important to him/her to protect the weak & 0.68 \\
\hline $\begin{array}{l}\text { 12. It is important for him/her to benefit those around him/her and take care of their well-being. } \\
\text { He/she tries to support those close to him/her }\end{array}$ & 0.68 \\
\hline 18. It is important for him/her to be loyal to his/her friends & 0.67 \\
\hline $\begin{array}{l}\text { 19. He/she is convinced that people should take care of nature. It is important for him/her to take } \\
\text { care of the environment }\end{array}$ & 0.64 \\
\hline $\begin{array}{l}\text { 33. He/she tries to see only good in people. He/she believes he/she must be prepared to forgive and } \\
\text { have no resentment against other people who have offended him/her }\end{array}$ & 0.59 \\
\hline $\begin{array}{l}\text { 23. He/she believes that all people of the world should live in harmony. It is important to him/her to } \\
\text { promote peace among all groups of people in the world }\end{array}$ & 0.57 \\
\hline 36. It is important for him/her to be courteous to other people. He tries not to annoy or disturb others & 0.56 \\
\hline $\begin{array}{l}\text { 40. It is important for him/her to be in harmony with nature, to be part of it. He/she believes that } \\
\text { people should not change nature too much }\end{array}$ & 0.56 \\
\hline 35. Stability in the state is important for him/her & 0.53 \\
\hline $\begin{array}{l}\text { 14. The security of the country is very important to him/her. He/she believes that the state must be } \\
\text { ready to defend itself against external and internal threats }\end{array}$ & 0.51 \\
\hline $\begin{array}{l}\text { 8. It is important for him/her to listen to people's opinions that differ from his/her perspective. Even } \\
\text { if he/she disagrees, he/she still tries to understand them }\end{array}$ & 0.44 \\
\hline $\begin{array}{l}\text { 16. It is important for him/her to behave properly. He/she tries to avoid doing things that people } \\
\text { would consider wrong }\end{array}$ & 0.44 \\
\hline
\end{tabular}

\section{Factor 2}

17. It is important for him/her to be a leader and tell others what to do

0.81

13. It is important for him/her to succeed and be an orientation target for other people. He/she likes to impress them

4. It is important for him/her to show his/her abilities and talents. He/she wants people to admire what he/she does

39. It is important for him/her to acquire authority, to have an influence on others

24. He/she believes it is important to be ambitious in life, to strive to achieve success according to his/her personal goals. He/she wants to demonstrate how capable he/she is

2. He/she tends to be rich and have expensive things

15. He/she likes to take risks and seeks adventures

\section{Factor 3}

31. It is important to be healthy for him/her

11. It is important for him/her to decide for himself/herself what to do. He/she likes to make his/her own decisions in planning and choosing his/her activities

34. It is important for him/her to be independent. He/she likes to rely on his/her own strength

32. It is important for him/her to develop and advance constantly. He/she strives to do everything better than others 
Table 2. Cont.

\begin{tabular}{|c|c|}
\hline Initial Variables, Explaining Factors & Factor Loadings \\
\hline $\begin{array}{l}\text { 6. He/she always strives for novelty and believes that it is important to do many different things } \\
\text { in life }\end{array}$ & 0.54 \\
\hline $\begin{array}{l}\text { 22. He/she believes that it is important to be a versatile person and be interested in many things. } \\
\mathrm{He} / \text { she likes to be inquisitive }\end{array}$ & 0.47 \\
\hline 1. He/she likes to do things his/her own way, do something new and be inventive & 0.45 \\
\hline 21. He/she does not like disorders. It is important to him/her to keep things clean and tidy & 0.43 \\
\hline \multicolumn{2}{|l|}{ Factor 4} \\
\hline 26. He/she likes not to deny himself/herself anything and enjoy life & 0.64 \\
\hline $\begin{array}{l}\text { 10. He/she is always looking for a reason to have fun. It is important for him/her to do things that } \\
\text { give him/her pleasure }\end{array}$ & 0.62 \\
\hline $\begin{array}{l}\text { 30. He/she loves surprises. It is important to him/her that his/her life should be full of bright } \\
\text { impressions }\end{array}$ & 0.53 \\
\hline 37. He/she is a swinger and likes to spend his/her free time well & 0.48 \\
\hline \multicolumn{2}{|l|}{ Factor 5} \\
\hline $\begin{array}{l}\text { 5. It is important for him/her to live in a safe environment. He/she avoids anything that might } \\
\text { threaten his/her safety }\end{array}$ & 0,60 \\
\hline 7. He/she believes that people should adhere to the established rules, even when no one sees them & 0.44 \\
\hline \multicolumn{2}{|l|}{ Factor 6} \\
\hline $\begin{array}{l}\text { 9. He/she believes that people should be happy with what they have at the moment and not ask for } \\
\text { more from others }\end{array}$ & 0.72 \\
\hline 20. Religion is important to him/her in life. He/she strives to follow his/her religious beliefs & 0.53 \\
\hline $\begin{array}{l}\text { 25. He/she believes that he/she should act according to established traditions. It is important for } \\
\text { him/her to observe the customs he/she has learned in life }\end{array}$ & 0.46 \\
\hline 38. It is important for him/her to be modest. He/she tries not to draw attention to himself/herself & 0.40 \\
\hline \multicolumn{2}{|l|}{ Factor 7} \\
\hline 3. He/she believes that everyone should have equal rights and opportunities in life & 0.64 \\
\hline
\end{tabular}

As a result of the interpretation, the synthetic indices were named as follows:

1. Taking care of people and the world around us;

2. Achieving a position;

3. Self-development;

4. Enjoyment of life;

5. Safe environment;

6. Traditionalism;

7. Equality.

The relationship of the indices with the basic values according to the initial variables is presented in Table 3.

It can be concluded that there is a stable positive relationship between the different basic values from the respondents' point of view:

Conformity-Benevolence-Universalism;

Achievement-Power. 
Table 3. Contingence of synthetic indices with basic human values.

\begin{tabular}{|c|c|c|c|c|c|c|c|}
\hline \multirow[b]{2}{*}{ Values } & \multicolumn{7}{|c|}{ Indices } \\
\hline & $\begin{array}{l}\text { 1-Taking Care of } \\
\text { People and the } \\
\text { World around US }\end{array}$ & $\begin{array}{c}2- \\
\text { Achieving a } \\
\text { Position }\end{array}$ & $\begin{array}{c}\text { 3-Self- } \\
\text { Development }\end{array}$ & $\begin{array}{l}\text { Enjoyment } \\
\text { of Life }\end{array}$ & $\begin{array}{l}\text { 5-Safe En- } \\
\text { vironment }\end{array}$ & $\frac{6-}{\text { Traditionalism }}$ & $\begin{array}{c}7- \\
\text { Equality }\end{array}$ \\
\hline Independence & - & - & 5 & - & - & - & - \\
\hline Stimulation & - & 1 & 1 & 1 & - & - & - \\
\hline Hedonism & - & - & - & 3 & - & - & - \\
\hline Achievement & - & 3 & 1 & - & - & - & - \\
\hline Power & - & 3 & - & - & - & - & - \\
\hline Safety & 2 & - & 1 & - & 1 & - & - \\
\hline Conformity & 4 & - & - & - & 1 & 1 & - \\
\hline Traditionalism & - & - & - & - & - & 3 & - \\
\hline Benevolence & 4 & - & - & - & - & - & - \\
\hline Universalism & 4 & - & - & - & - & - & 1 \\
\hline
\end{tabular}

Next, respondents were classified according to the newly obtained indices using a twostage cluster analysis, where the Bayesian information criterion was used as the clustering criterion. Four clusters were obtained as a result of clustering. In order to determine the profiles of the clusters, we plotted the average values of the indices by clusters (Figure 2).

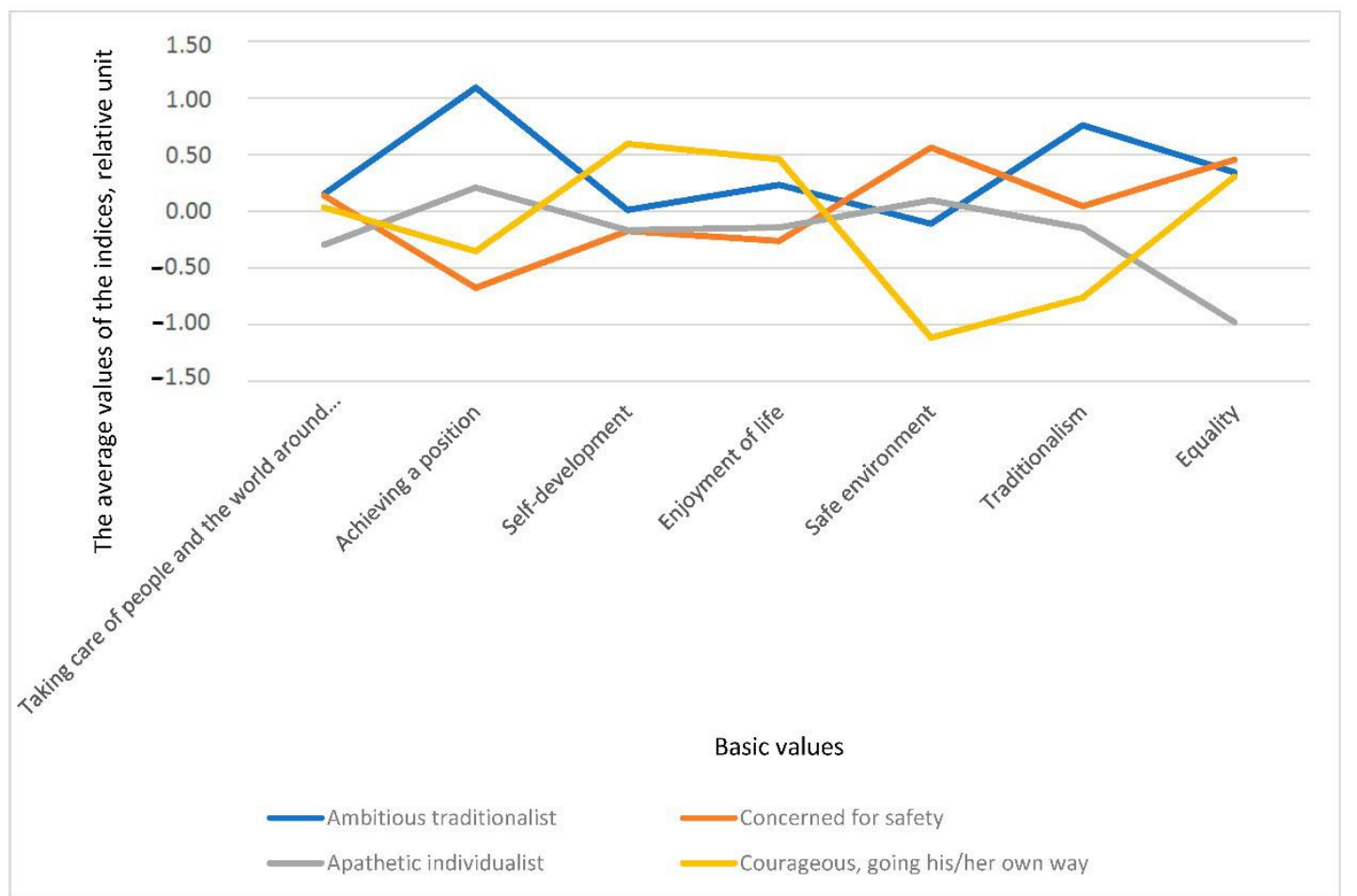

Figure 2. The plot of the average values of the indices of the 4 clusters for the basic values of the respondents.

Based on the analysis results of the sizes and profiles of the clusters (average plots), we can characterize them as value clusters to the basic values of the respondents as follows:

1 st cluster (21\% of respondents) - Ambitious traditionalists who strive to achieve a high position in society and hold traditional views;

2nd cluster (33\%)-Concerned for safety respondents who strive for safety, position in the society is not important;

3rd cluster (28\%)-Apathetic individualists who are not interested in equal rights and care of others; 
4th cluster (17\%)-Courageous, going their way respondents who strive to develop and get satisfaction from life, not interested in security and traditions.

The distribution of cluster representatives by age and gender is shown in Figures 3 and 4 .

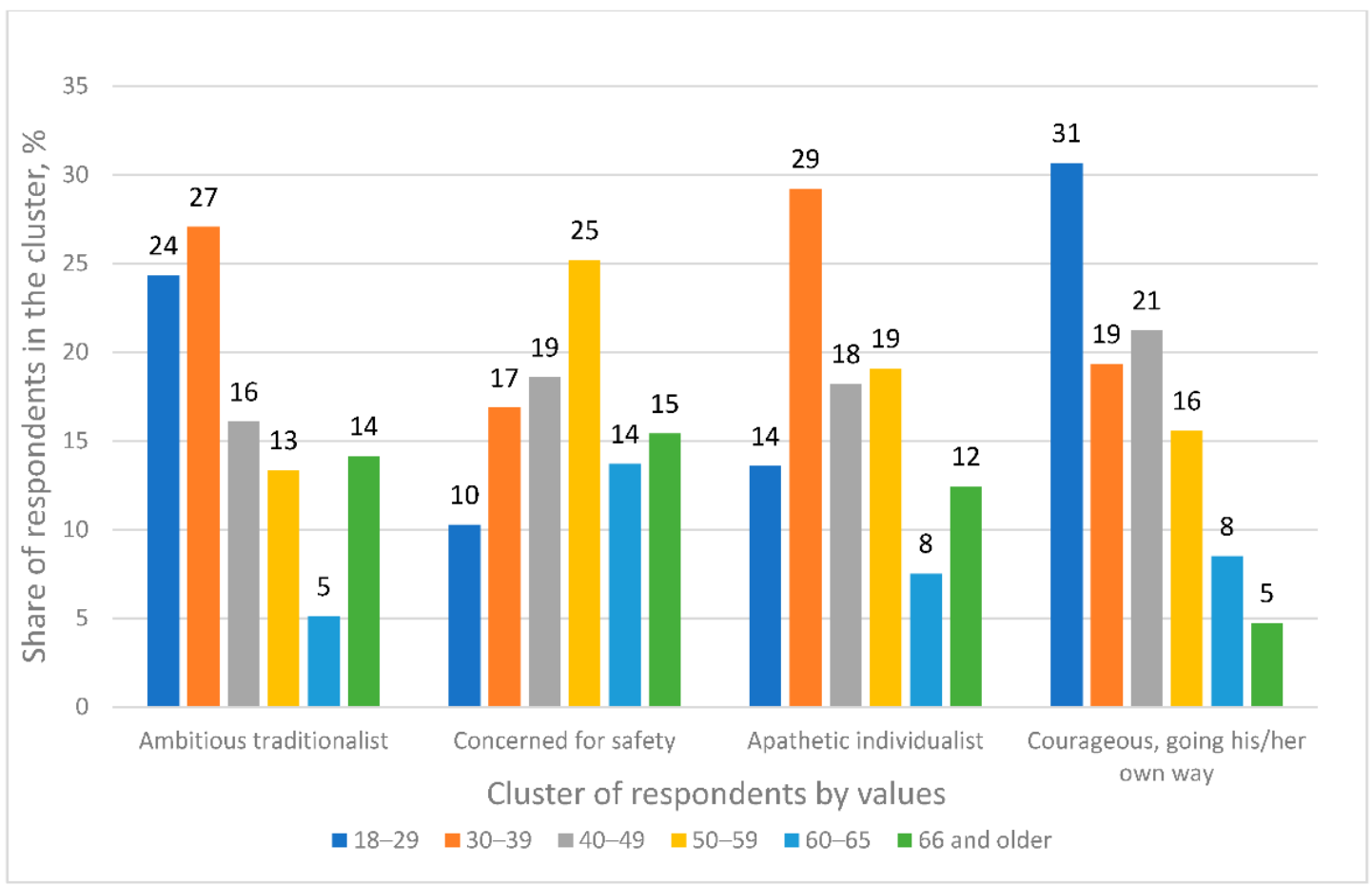

Figure 3. Distribution of representatives of the 4 clusters by age.

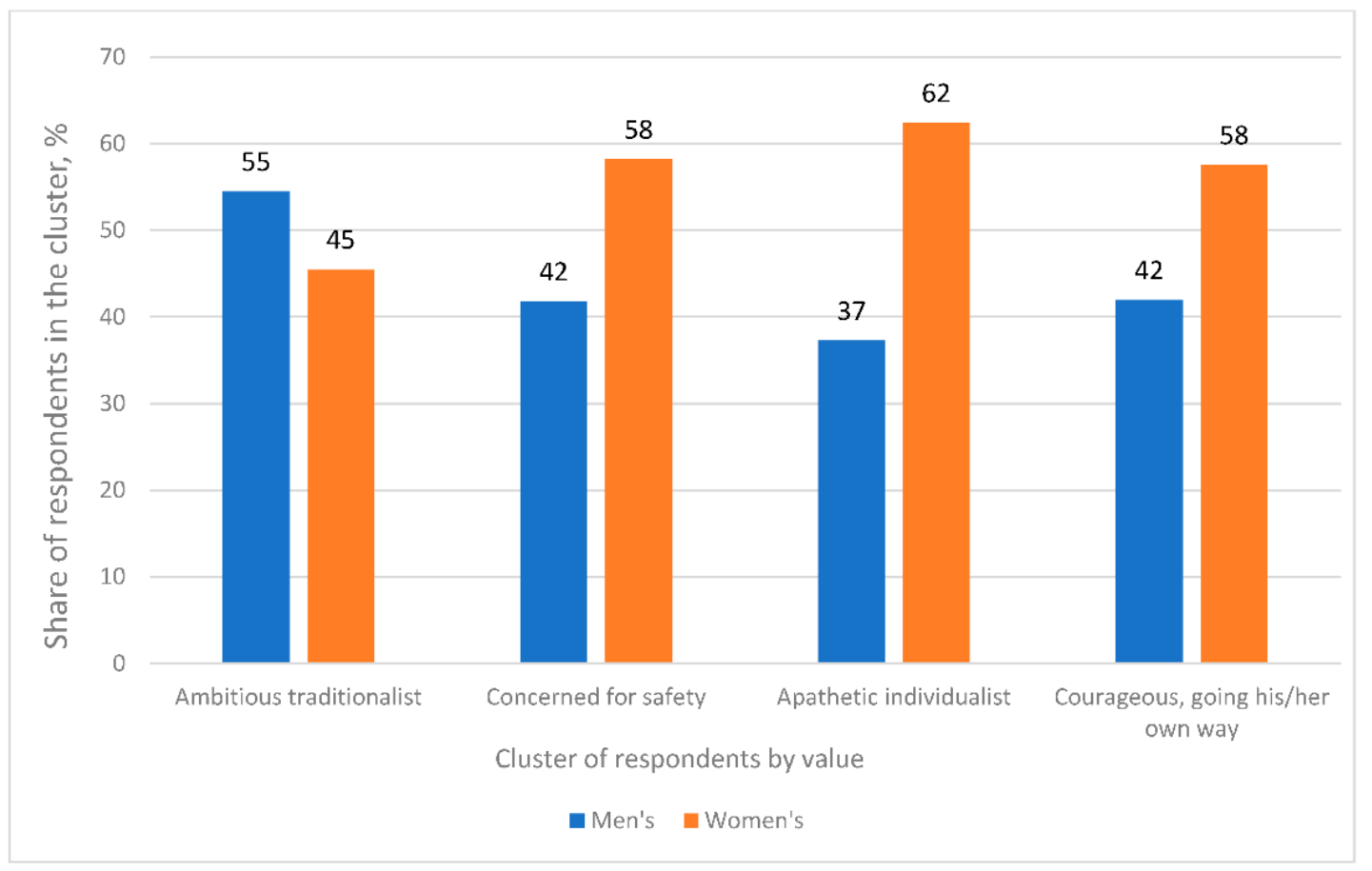

Figure 4. Distribution of respondents by gender in the 4 clusters. 
The highest proportion of cluster representatives by age:

1st (Ambitious traditionalists) - respondents from 18 to 39 years old (51\% of respondents);

2nd (Concerned for safety) - respondents from 50 to 59 years old (25\%);

3rd (Apathetic individualists)—respondents from 30 to 39 years old (29\%). Interestingly, $\frac{1}{4}$ of representatives of this cluster lives in the Southern (11\%) and Central (11\%) districts of Moscow;

4th (Courageous, going their own way) - respondents from 18 to 29 years old (31\% of the respondents).

Figure 4 shows the distribution of respondents by gender in the 4 clusters.

Men outnumber women only in cluster 1 (Ambitious traditionalists-by 17\%); in other clusters, women prevail, especially in cluster 3 (Apathetic individualists)—women outnumber men by $2 / 3$.

Figures 5 and 6 show the distribution of cluster representatives by employment status and educational level of respondents.

The largest share of cluster representatives by employment status is full-time working (from $46 \%$ to $61 \%$ of respondents); among the representatives of the 2 nd cluster (Concerned about security), there is a significant proportion of pensioners (32\%).

The vast majority of respondents in all clusters have higher education (from $66 \%$ to $75 \%$ ); among the representatives of the 1st cluster (Ambitious traditionalists), there is the smallest proportion of respondents with secondary general education $(5 \%)$.

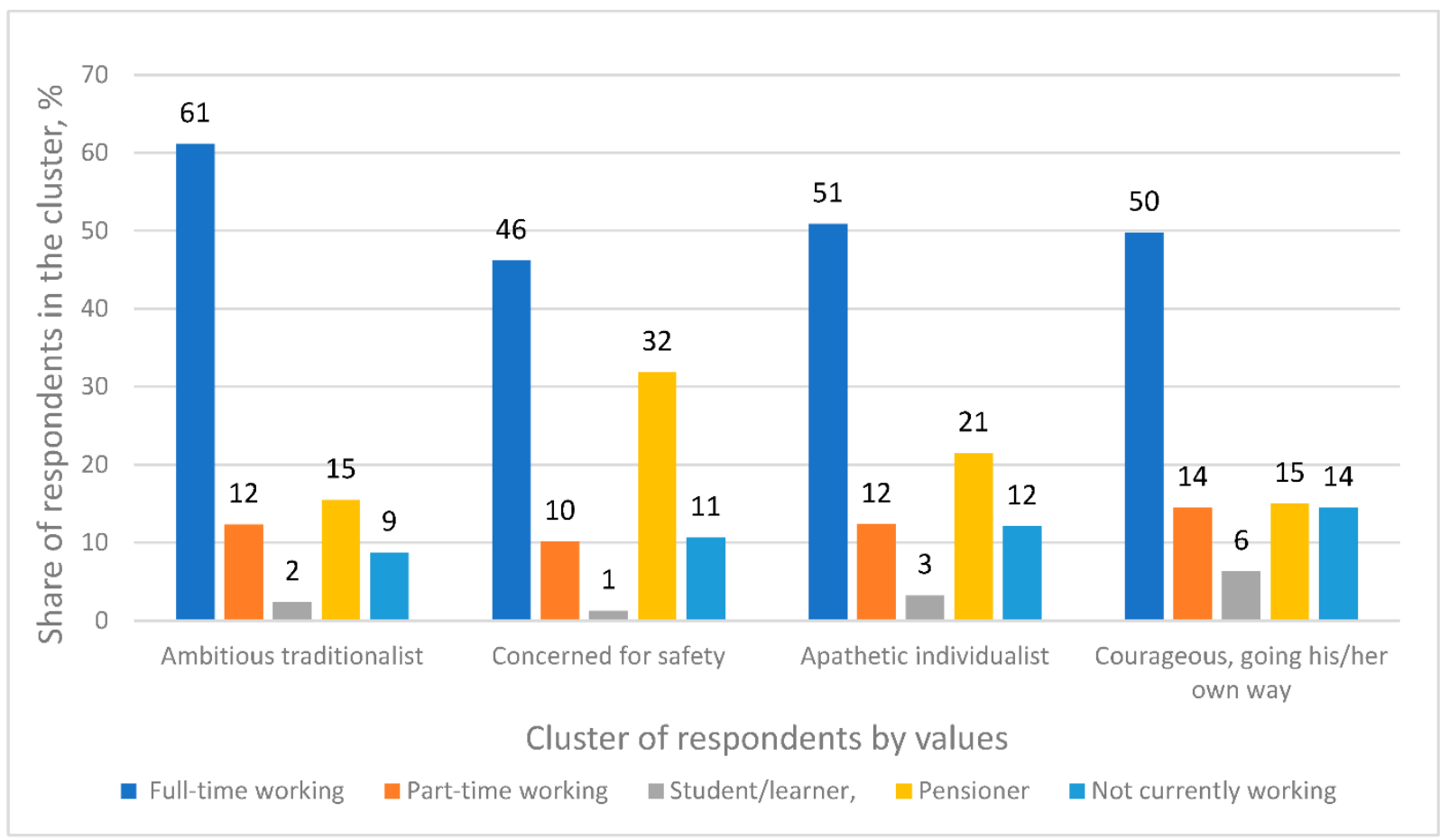

Figure 5. Distribution of cluster representatives by employment status. 


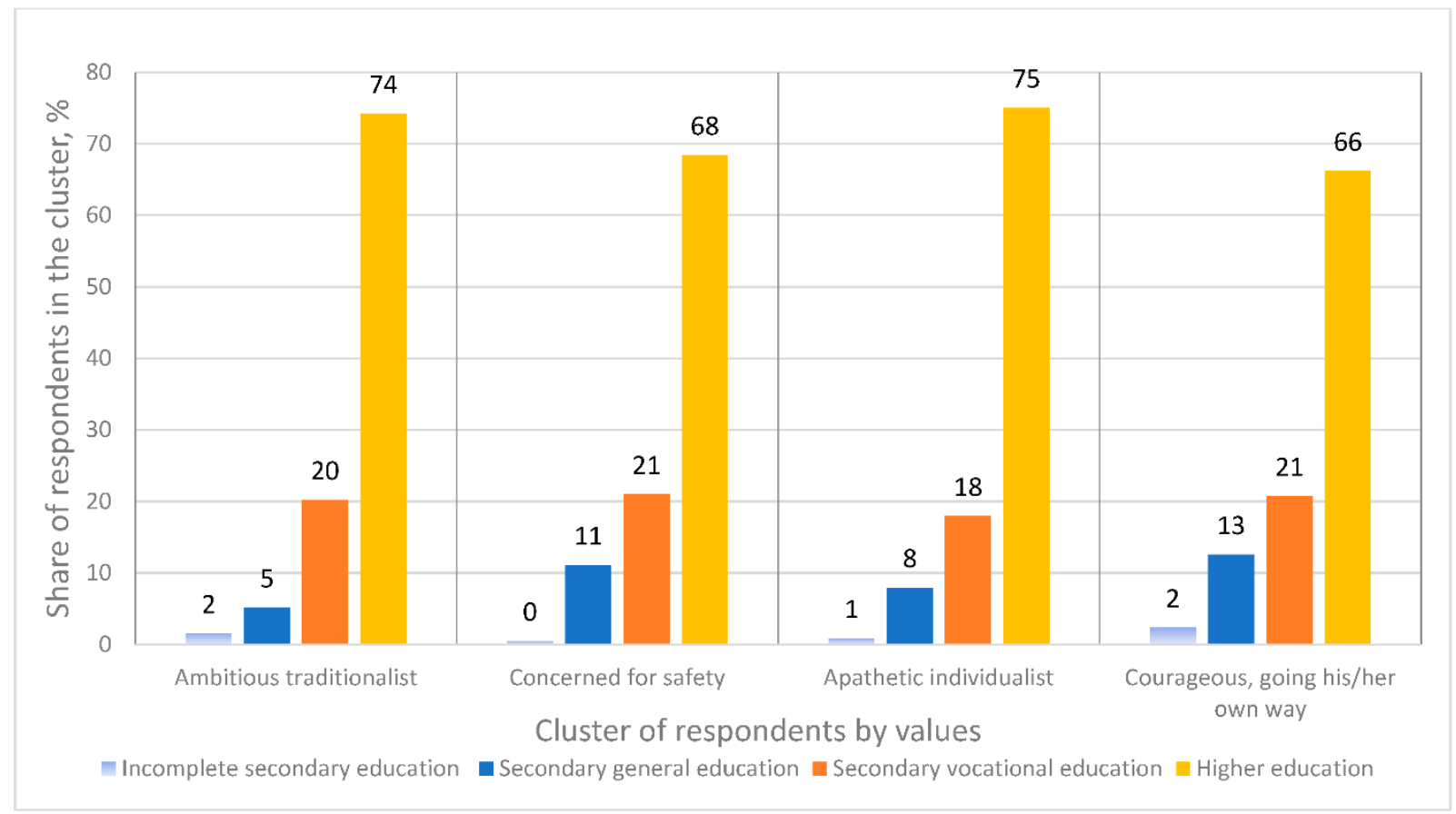

Figure 6. Distribution of cluster representatives by educational level.

\subsection{Stage 2. Testing Hypotheses 1 and 2}

Figure 7 shows measures in the transport field, which, according to respondents, the authorities should introduce first of all to improve the environment in the city.

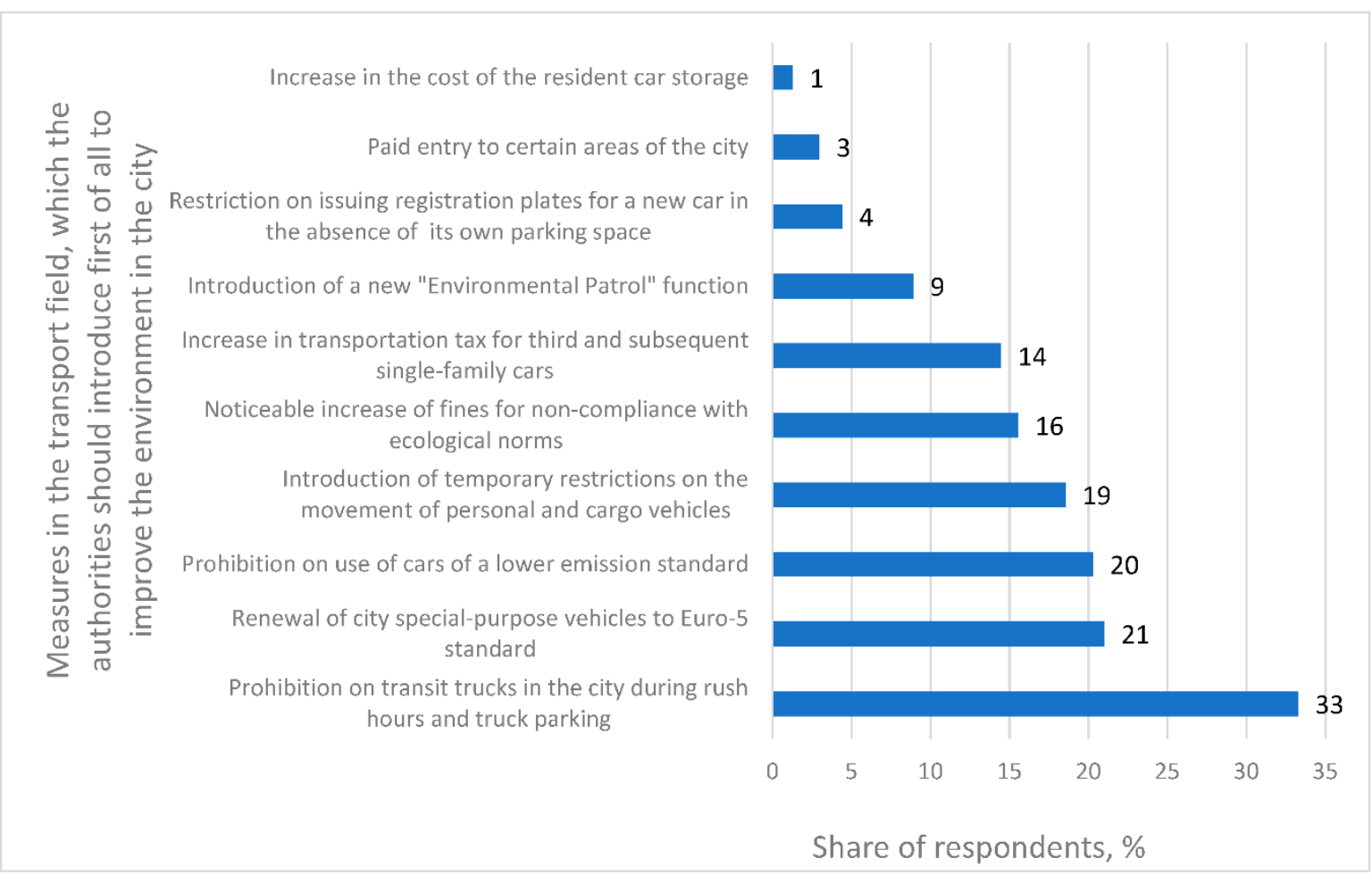

Figure 7. Measures in the transport field, which the authorities should introduce first of all to improve the environment in the city. 
From the respondents' point of view, the most important measure is the prohibition of transit trucks in the city during rush hours and the parking of trucks in non-specialized places (33\%).

Statistically significant (based on chi-square test at $5 \%$ significance level) relationships of respondents' cluster membership were revealed concerning basic values and answers to the questions:

- Do the city authorities pay enough attention to environmental issues?

- Do you agree with the statement that residents are equally responsible for the environmental situation in the city?

Figure 8 shows the results of the comparative analysis of whether the city authorities pay enough attention to environmental issues.

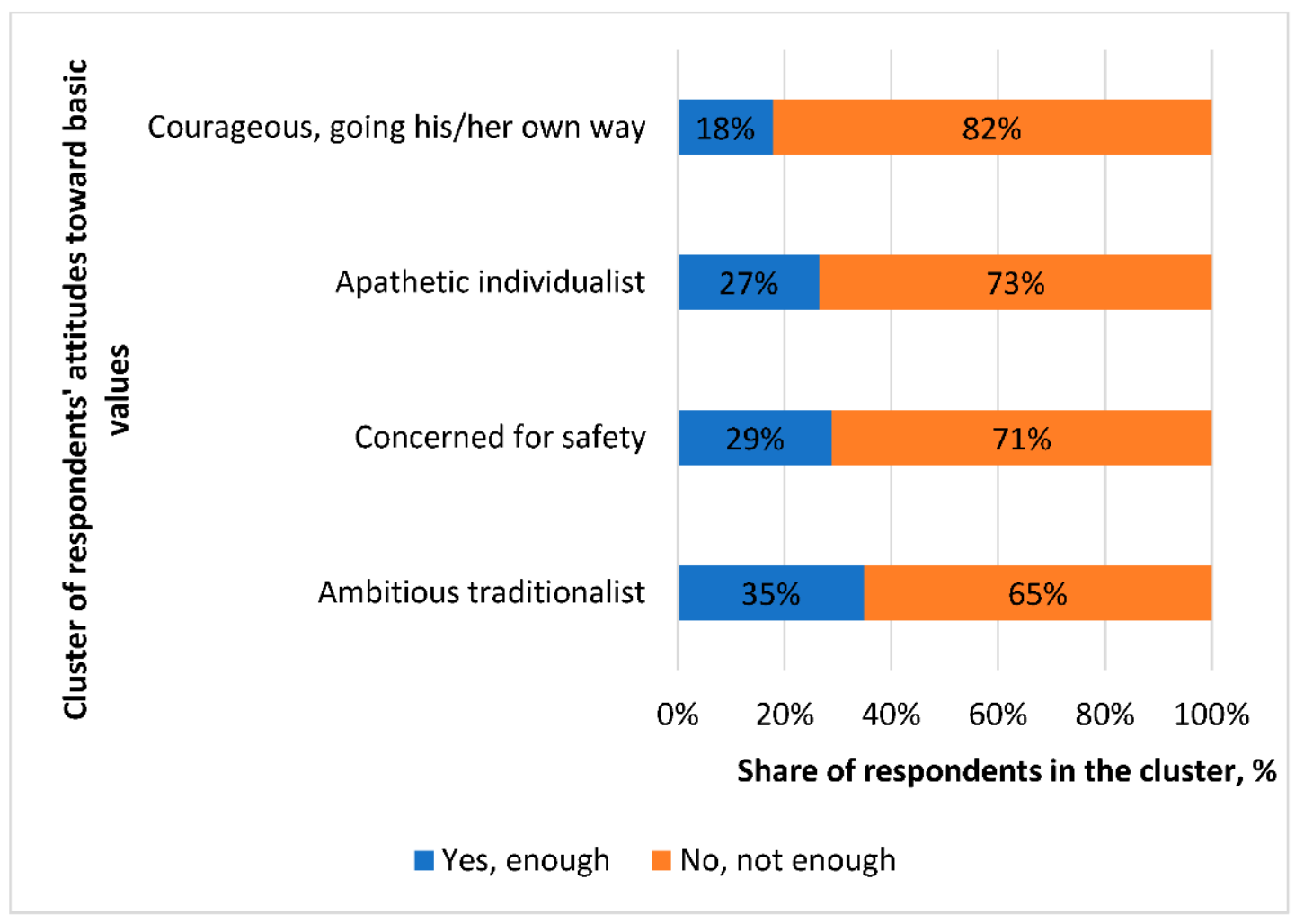

Figure 8. The city authorities pay enough or not enough attention to environmental issues.

Among Ambitious traditionalists, the maximum proportion believes that the authorities pay sufficient attention to environmental issues ( $35 \%$ of respondents). The lowest proportion is among Courageous, going their own way respondents (18\%). Thus, among Ambitious traditionalists, the largest proportion of people is ready to solve the city's environmental problems with the authorities actively; the smallest is among Courageous, going their way respondents.

The attitude of the representatives of different clusters to the actions of the city authorities to develop environmental transport (significance level of 5\%, except for the expansion of electric transport network-8\%) is shown in Figures 9 and 10. 


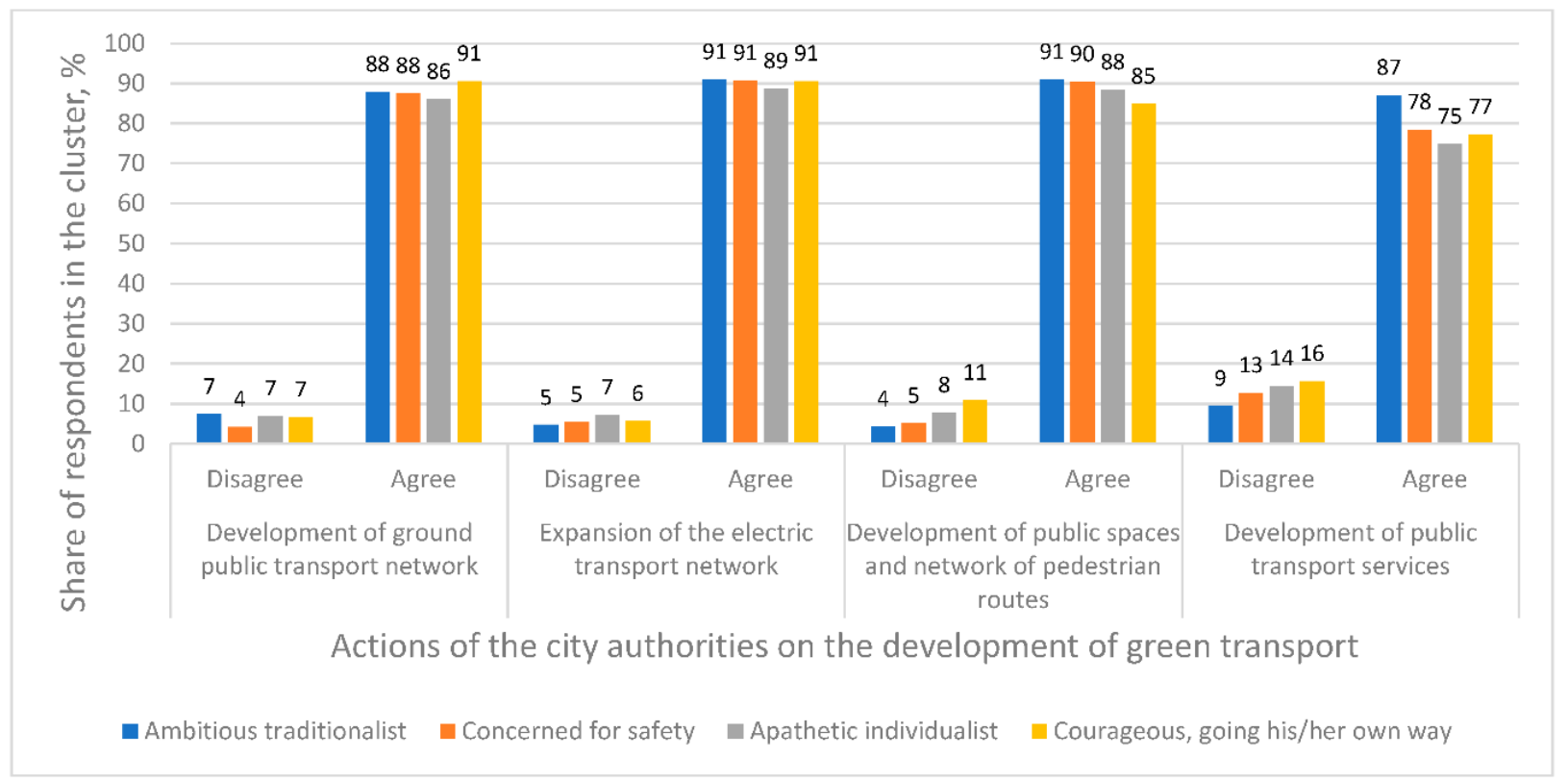

Figure 9. The attitude of representatives of the four clusters towards the actions of the city authorities to develop environmental transport (in terms of answers to the questions on the development of ground public transport network; expansion of electric transport network; development of public spaces and network of pedestrian routes; development of public transport services).

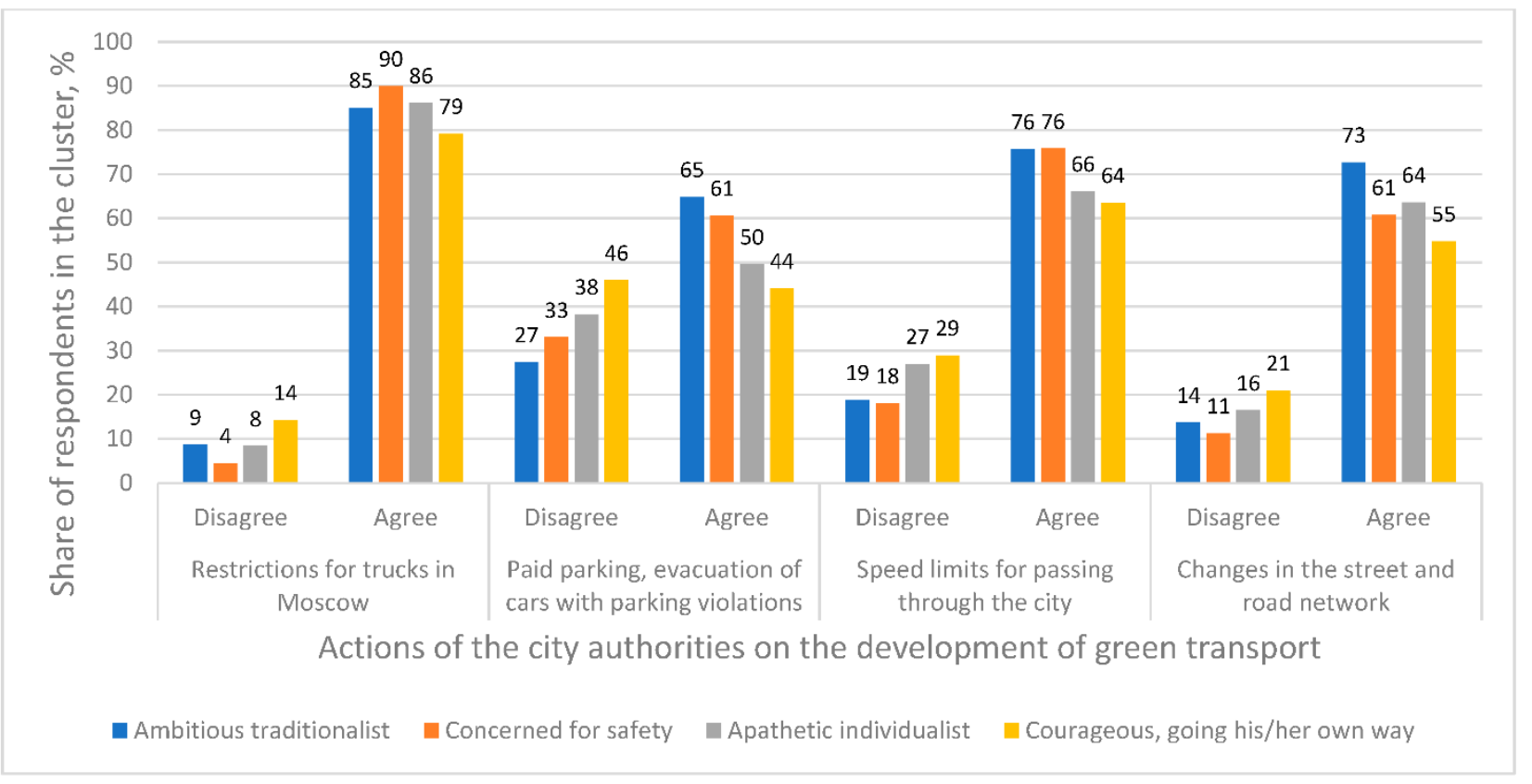

Figure 10. The attitude of representatives of the four clusters towards the actions of the city authorities to develop environmental transport (in terms of answers to the questions on restrictions for trucks in Moscow; paid parking, evacuation of cars with parking violations; speed limits for passing through the city; changes in the street and road network).

Among the representatives of the clusters, the highest proportion of respondents agrees with the actions of the authorities in the following areas (from 85 to 91\%): the development of the ground public transport network; expansion of the electric transport network; development of public spaces and network of pedestrian routes; restrictions on the passage of trucks through Moscow. At the same time, we can see less support in the clusters for some environmental initiatives: 
1st cluster (Ambitious traditionalists)—development of paid parking lots (65\%), changes in the street and road network $(73 \%)$ and speed limits $(76 \%)$;

2nd cluster (Concerned for safety) - development of paid parking (61\%), changes in the street and road network (61\%), speed limits $(76 \%)$, and development of public transport services $(78 \%)$;

3rd cluster (Apathetic individualists)—development of paid parking $(50 \%)$, changes in the street and road network (64\%), speed limits $(66 \%)$, and development of public transport services $(75 \%)$;

4th cluster (Courageous, going their own way) - development of paid parking (44\%), changes in the street and road network (55\%), speed limits (64\%), development of public transportation services $(77 \%)$, and restrictions on the passage of trucks $(79 \%)$.

It is noteworthy that the actions of the Moscow authorities in the field of the environment, with which the majority of representatives of all clusters agree concerning the respondents' basic values (development of the ground public transport network; expansion of electric transport network; development of public spaces and network of pedestrian routes; restrictions on trucks passing through Moscow) primarily contribute to further improvement of the most important factor of the environmental situation—air quality.

Figure 11 shows the results of the comparative analysis of the degree of agreement with the fact that residents are responsible for the environmental situation in the city on an equal footing with the city authorities.

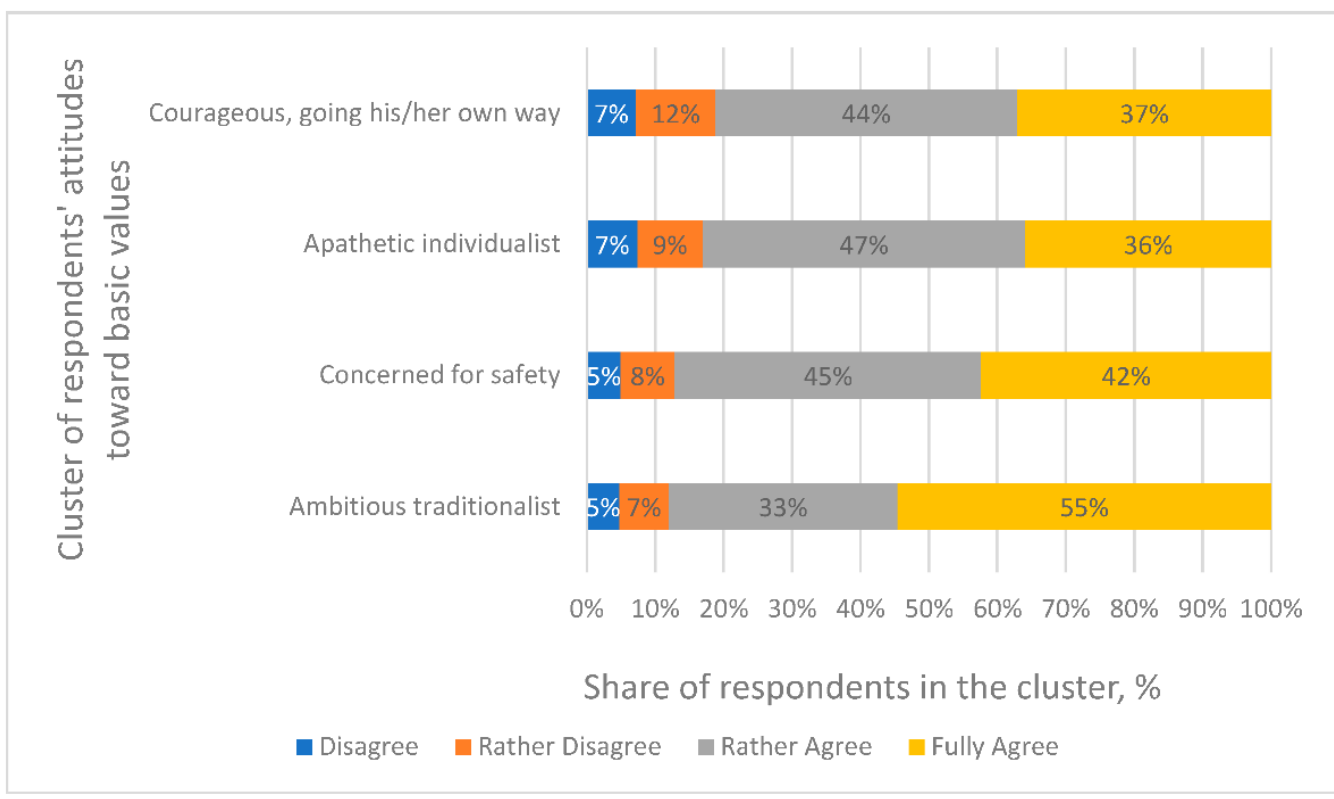

Figure 11. Degree of agreement with the fact that residents are responsible for the environmental situation in the city on an equal footing with the city authorities.

The highest proportion of people (more than half-55\%) who fully agree that residents, on an equal footing with the authorities, should be involved in improving the urban environment is among Ambitious traditionalists, and they have the highest proportion of those who agree in principle with this statement (88\%). The smallest proportion (although significant) of those who agree with this statement is among the Courageous, going their own way respondents- $81 \%$.

\subsection{Stage 3: Comparative Analysis of the Objective State and Changes in the Quality of the Environment of the City and the Perception of the Ecology of the City by Residents}

We analyzed trends in concentrations of major pollutants in Moscow based on state statistics data for 5 years from 2016 to 2020 . The choice of atmospheric air pollution indicators is described in the literature [4]. The results are presented in Table 4. 
Table 4. Trends in concentrations of major pollutants in Moscow.

\begin{tabular}{cccccc}
\hline & \multicolumn{4}{c}{ The Average Concentration in Moscow, $\mathbf{m g} / \mathbf{m}^{\mathbf{3}}$} \\
\cline { 2 - 6 } Year & Carbon Oxide & Sulfur Dioxide & Nitrogen Dioxide & Nitrogen Oxide & $\begin{array}{c}\text { Ground-Level } \\
\text { Ozone }\end{array}$ \\
\hline 2016 & 0.38 & 0.0030 & 0.35 & 0.018 & 0.031 \\
2017 & 0.36 & 0.0034 & 0.34 & 0.016 & 0.028 \\
2018 & 0.38 & 0.0037 & 0.35 & 0.019 & 0.030 \\
2019 & 0.32 & 0.0032 & 0.31 & 0.015 & 0.034 \\
2020 & 0.28 & 0.0029 & -17 & -17 & -6 \\
Change over & -26 & -3 & & & \\
5 years, \% & & & & 0.029 \\
\hline
\end{tabular}

For five last years (from 2016 to 2020), all indicators for pollutant gases of the atmosphere decreased by more than $3 \%$, and carbon monoxide by $26 \%$.

At the same time, when answering the question "In your opinion, how has the ecological situation in Moscow changed over the last five years?" the respondents' answers (Figure 12) contradict the objective observation data. Over the last five years, the air quality in Moscow has improved significantly. The report on the environmental conditions in Moscow in 2020 [95] presents the data on the change in emissions of harmful substances into the atmosphere (Table 4).

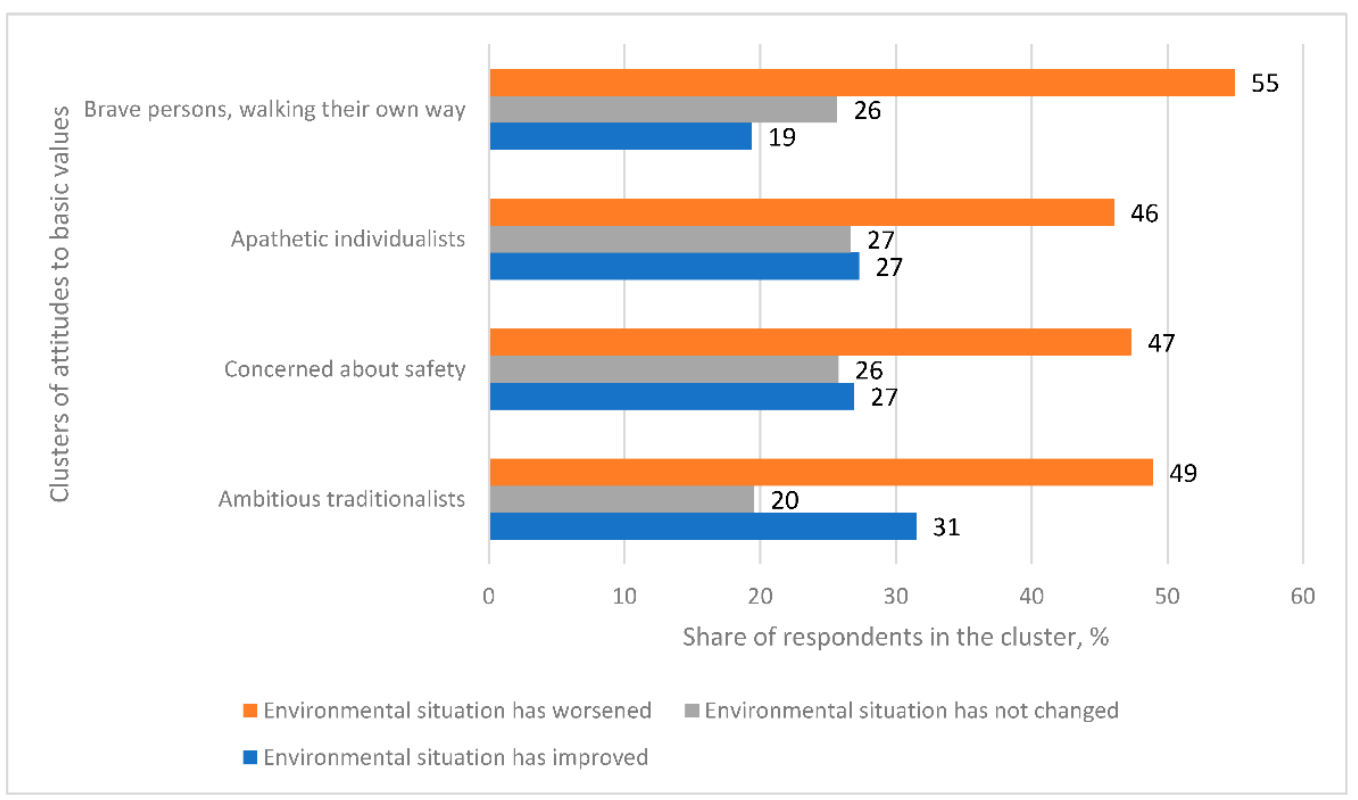

Figure 12. Numerical distribution of respondents' answers to changes in the environmental situation by cluster.

\section{Discussion}

The empirical results we obtained, in which residents' opinions differ on the measures introduced to enhance the sustainable development of urban public transport system confirm the opinions of researchers (such as [45-48]) about the impossibility to implement innovation without considering the opinions and assessments of the city population. At the same time, taking into account the analysis of the issue history in the literature, it should be noted that the influence of values on the attitude of residents to the environmental initiatives of the authorities is poorly studied. Many works point out the necessity of understanding the residents' values to study this issue $[47,60,61]$. Our study showed that in the part of the initiatives that do not affect the respondent personally but potentially provide more comfort and mobility, differences in assessments were not significant in 
all value clusters. Simultaneously, here was the greatest support for these innovations. In this regard, our analysis of the empirical data obtained only partially confirmed the hypothesis (H1).

At the same time, in the same value clusters, these environmental transport innovations would require the respondent to incur extra charges (paid parking, speed limits, and changes in the street and road network), sharply reducing the support of such innovations by the respondents. Here was also noted the widest scatter in assessments, depending on the values, which demonstrates a partial confirmation of the hypothesis put forward. In addition, although some researchers $[20,58,59]$ emphasize that citizens play a key role in the process of sustainable transport development because they actively participate in implementing them and the influence of their selfish motives should be considered, which is consistent with the problem of acceptance of innovation described in the literature [2,3].

The literature indicates that addressing congestion, air pollution, and greenhouse gas emissions requires an increased demand for innovative transportation policies [53-55], which is impossible without the support of residents. Our results showed a high level of personal responsibility of residents for the environmental situation in the city as a result of the development of the urban transportation system (H2 was confirmed). The share of respondents who agree or agree in the aggregate exceeds $80 \%$ for all selected value clusters. It is especially important given the Russian specifics described in the Literature Review section. The results obtained are consistent with the studies presented in the literature, which note that implementing innovation within the smart city concept is impossible without population participation, which is expressed in opinions, assessments, and suggestions [37-44].

Since residents' perception of the environmental situation is subjective, individual characteristics and values can influence it. The literature notes that residents' attitudes toward levels of air pollution and other types of pollution underlie decision-making [56,57]. In addition, the literature often uses clustering in the context of studying attitudes toward climate change and air pollution [78]. In contrast to other researchers, in our work, we used values to cluster the respondents. We analyzed their differences in the attitude to urban innovation for the sustainable development of the urban public transport system.

The comparison of subjective perception of the environmental situation in the city and the actual environmental conditions confirmed the hypothesis (H3). In conditions when objective data shows that the environmental situation in the city is improving, residents believe that the situation has worsened. Such a subjective perception of the environmental situation by the residents carries the problem of inertia to cope with the changes, which certainly negatively affects the residents' opinion on the actions of the authorities. The result obtained demonstrates the gap between perception and reality, and perhaps the resulting inertia is associated with poor coverage of environmental changes in the city by the media. We believe that additional research is needed to investigate the causes of the mismatch between perception and reality.

\section{Conclusions}

Based on the results of our empirical research on a sample of 2275 respondents, it was demonstrated that the following values were most relevant for the respondents: Safety3.38 points; Independence- 3.22 points; Conformity -3.21 points. The least corresponded to the respondents' values: Power-1.8 points; Stimulation-1.8 points.

Based on the analysis results of the sizes and profiles of the clusters (mean plots), we can characterize the clusters concerning the basic values of the respondents as follows:

1 st cluster (21\% of respondents) - Ambitious traditionalists who strive to achieve a high position in society and hold traditional views;

2nd cluster (33\%) - Concerned for safety respondents who strive for safety, position in the society is not important;

3rd cluster (28\%)-Apathetic individualists who are not interested in equal rights and care of others; 
4th cluster (17\%)—Courageous, going their way respondents who strive to develop and get satisfaction from life, not interested in security and traditions.

Among the representatives of the clusters, the highest proportion of respondents agreed with the actions of the authorities in the following areas:

1st (Ambitious traditionalists) - a large proportion agree on all directions (from 85 to $91 \%)$, except for paid parking lots (65\%), changes in the street and road network $(73 \%)$ and speed limits $(76 \%)$;

2nd (Concerned for safety) - a large proportion agree on all directions (88 to 91\%) except for paid parking $(61 \%)$, changes in the street and road network (61\%), speed limits $(76 \%)$, and development of public transportation services (78\%);

3rd (Apathetic individualists) - a large proportion agree on all directions (from 86 to $89 \%)$ except for paid parking $(50 \%)$, changes in the street and road network $(64 \%)$, speed limits (66\%), and development of public transport services (75\%);

4th (Courageous, going their own way) - a large proportion agrees in all directions (from 85 to $91 \%$ ), except for paid parking (44\%), changes in the street and road network (55\%), speed limits $(64 \%)$, development of public transport services $(77 \%)$ and restrictions for passage of trucks $(79 \%)$.

The largest proportion of dissents is on paid parking (from $27 \%$ for Cluster 1 to $46 \%$ for Cluster 4), speed limits (from 18\% for Cluster 2 to $29 \%$ for Cluster 4), and changes to the street and road network (from $11 \%$ for Cluster 2 to $21 \%$ for Cluster 4 ).

\subsection{Theoretical Implication}

The important theoretical implications of our study are as follows: First, based on the literature and collected empirical data, our study provided a basis for using Schwartz's value theory $[67,91,93]$ to examine residents' attitudes toward environmental development of urban public transport. The literature review demonstrated an emerging need for research capable of identifying and analyzing problems and seeking innovative solutions to existing urban public transport problems [6]. The study's novelty is due to, first of all, identified causeand-effect relationships between values and the reaction of individuals to environmental initiatives aimed at the sustainable development of urban public transport systems.

Second, the study results shed light on the reasons for the differences in respondents' attitudes toward the actions of city authorities to develop environmental transport. In general, the analysis of the study results allows us to conclude that the attitude to the actions of the city authorities, aimed at improving the environmental situation by changing the transport system, will differ among residents with different values. The initiatives that do not personally affect the individual and do not require efforts on the part of the individual to change his transportation behavior find the unanimous support of the environmental initiatives of the city authorities for the development of sustainable urban public transport. For such initiatives, the level of support ranges from $85 \%$ to higher in all clusters.

At the same time, environmental transport innovations that require additional effort from the respondent sharply lose their support, and we observe differences in the perception of such initiatives in the value clusters.

Thus, understanding the importance of taking into account the opinion of residents in the development of the metropolitan transport system, as presented in the literature [49-52], should be understood that any innovations that require changes in individuals behavior restrict or control their transport behavior, and require additional costs on their part, will meet resistance even if they change people's mobility towards sustainable mobility. Therefore, we can assume that residents' inertness and unwillingness to change the consumer patterns of transport behavior actively do not increase demand for innovative transport policy, and there is a need for stimulating measures.

Third, our comparative analysis of the objective state of the urban environment and subjective assessments of the residents of this state showed significant differences between the real state and perception. When the environmental situation in the city improves, residents believe that it has become worse. The obtained result opens a new area 
requiring scientific research and identification of factors that could scientifically explain these differences and suggest ways to bridge the existing gap.

\subsection{Practical Implication}

In turn, the identified inertia of perception of environmental change requires increased efforts from the city authorities to overcome it, including additional communications to inform residents about the metropolis's environmental situation.

As other practical consequences of our study, it should be noted that our data allow us not only to record the respondents' attitudes towards the environmental transport initiatives of the city authorities but also to understand the nature of their reactions, which means there is an opportunity to build a proper dialogue with the public and find explanations for people with different values of life. In our opinion, such an approach will help avoid and more easily overcome resistance to introducing environmental transport solutions in the metropolis.

It was also found that residents, referred to different value clusters, are ready to share responsibility for the environmental situation in the city on an equal footing with the city authorities, which is important to implement transport environmental innovations in the city, especially considering the Russian historical specifics, where residents passively observed the actions of the authorities and did not actively participate in the changes aimed at sustainable development.

We expect municipal authorities and transportation companies to use our findings to plan communication campaigns with city residents when implementing environmental initiatives, which greatly facilitates their adoption. In our opinion, this work contributes to a better understanding of the factors that determine users' perception of sustainable development of the urban public transport system.

\subsection{Limitations and Study Forward}

The study was conducted when the pandemic was developing, and city authorities recommended limited contacts, which could have influenced the bias in respondents' estimates. An online internet survey was used as the survey platform, which could also have influenced the relevance of respondents' answers. According to the research methodology, the sample's representativeness was controlled by such demographic indicators as age and gender. Other socio-demographic indicators used to describe the cluster profile were not specifically controlled. At the same time, the analysis of the socio-demographic profile of the respondents showed that the higher education status was widespread across the whole sample, which could affect the results obtained. This fact should also be attributed to the limitations of the study.

In addition, the lack of a basis for comparing respondents' attitudes in past periods regarding the environmental situation reduces the opportunity for comparative analysis. The authors see the way forward of the research in studying the influence of value and socio-demographic indicators on residents' attitudes to the environmental problems of urban transport.

Author Contributions: Conceptualization, R.R.S., A.V.L., S.V.M. and I.I.S.; methodology, R.R.S., A.V.L., S.V.M. and I.I.S.; software, S.V.M.; validation, R.R.S. and S.V.M.; formal analysis, A.V.L. and A.A.S.; investigation, R.R.S. and A.V.L.; resources, S.V.M.; data curation, S.V.M.; writing-original draft preparation, S.V.M.; writing-review and editing, R.R.S. and I.I.S.; visualization, S.V.M. and A.V.L.; supervision, R.R.S. and A.A.S.; project administration, R.R.S. and I.I.S. All authors have read and agreed to the published version of the manuscript.

Funding: This research received no external funding.

Institutional Review Board Statement: Ethical review and approval were waived for this study, due to the reason that the survey was anonymous as it is recommended by the International Chamber of Commerce and the European Society of Market and Public Opinion Research (ESOMAR) ICC/ESOMAR International Code on Market and Social Research. 
Informed Consent Statement: This study was organized via online survey, and it was anonymous, no personal information of the respondents was disclosed.

Data Availability Statement: The authors have conducted the online survey with the help of the SurveyMonkey planform. The link to the survey is https:/ / ru.surveymonkey.com $/ \mathrm{r} / \mathrm{NKYCWH2}$. It is also stated that no personal data of the respondents, besides the gender, age, and place of residence in Moscow, were included.

Acknowledgments: The authors would like to acknowledge gratitude to the professors and faculty of the Department of Marketing and the administration of PRUE for the support and technical assistance.

Conflicts of Interest: The authors declare no conflict of interest.

\section{References}

1. Sidorchuk, R.; Skorobogatykh, I. Marketing evaluation of public transport quality attributes: A review of two waves of research. Mediterr. J. Soc. Sci. 2015, 6, 275-282. [CrossRef]

2. Ram, S.; Sheth, J.N. Consumer resistance to innovations: The marketing problem and its solutions. J. Consum. Mark. 1989, 6, 5-14. [CrossRef]

3. Talke, K.; Heidenreich, S. Passive and Active Innovation Resistance. J. Prod. Innov. Manag. 2014, 31, 894-907. [CrossRef]

4. Anable, J.; Lane, B.; Kelay, T. An Evidence-Based Review of Public Attitudes to Climate Change and Transport Behaviour; The Department for Transport: London, UK, 2006.

5. Yun, J.J.; Won, D.; Park, K. Entrepreneurial cyclical dynamics of open innovation. J. Evol. Econ. 2018, 28, 1151-1174. [CrossRef]

6. Yun, J.J.; Zhao, X.; Jung, K.; Yigitcanlar, T. The Culture for Open Innovation Dynamics. Sustainability 2020, 12, 5076. [CrossRef]

7. Yun, J.J.; Kim, D.; Yan, M.-R. Open Innovation Engineering-Preliminary Study on New Entrance of Technology to Market. Electronics 2020, 9, 791. [CrossRef]

8. Zhang, L.; Huang, C.; Zhao, D.; Du, H.; Lu, Q.; Yu, H.; Zhang, M. Design optimization for urban landscape from the perspective of ecological chain, anti-planning and barrier free design: The unity of natural and social environmental benefits. Fresenius Environ. Bull. 2021, 29, 9095-9102.

9. Hou, X.; Wu, S.; Chen, D.; Cheng, M.; Yu, X.; Yan, D.; Peng, M. Can urban public services and ecosystem services achieve positive synergies? Ecol. Indic. 2021, 124, 107433. [CrossRef]

10. Jiang, B.; Huang, J. A new approach to detecting and designing living structure of urban environments. Comput. Environ. Urban Syst. 2021, 88, 101646. [CrossRef]

11. Kelilba, M.; Chaib, R.; Kahlouche, A. A sensitive approach to identify black spots in urban transport, with application to cities in Algeria. Transp. Probl. 2021, 16, 199-210. [CrossRef]

12. Leviäkangas, P.; Öörni, R. From business models to value networks and business ecosystems-What does it mean for the economics and governance of the transport system? Util. Policy 2020, 64, 101046. [CrossRef]

13. Scavarda, A.; Daú, G.; Scavarda, F.L.; Duarte Azevedo, B.; Korzenowski, L.A. Social and ecological approaches in urban interfaces: A sharing economy management framework. Sci. Total Environ. 2020, 713, 134407. [CrossRef]

14. Hörcher, D.; Tirachini, A. A review of public transport economics. Econ. Transp. 2021, 25, 100196. [CrossRef]

15. Miller, H.J. Movement analytics for sustainable mobility. J. Spat. Inf. Sci. 2020, 20, 115-123.

16. Nathanail, E.; Karakikes, I.; Mitropoulos, L.; Adamos, G. A sustainability cross-case assessment of city logistics solutions. Case Stud. Transp. Policy 2021, 9, 219-240. [CrossRef]

17. Olfindo, R. Transport accessibility, residential satisfaction, and moving intention in a context of limited travel mode choice. Transp. Res. Part A Policy Pract. 2021, 145, 153-166. [CrossRef]

18. Yonglong, L.; Xianghui, C.; Chenchen, W. Systematic transformation towards urban sustainable development. Shengtai Xuebao/Acta Ecol. Sin. 2019, 39, 1125-1134.

19. Mozūriūnaitè, S.; Sabaitytè, J. To what extent we do understand smart cities and characteristics influencing city smartness. J. Archit. Urban. 2021, 45, 1-8. [CrossRef]

20. Mitran, G.; Ilie, S.; Igret, S.V.; Mihailescu, S. Sustainable mobility as a result of peoples' awareness on environmental problems generated by transport activity. IOP Conf. Ser. Mater. Sci. Eng. 2019, 568, 012025. [CrossRef]

21. Sousa, S.; Correia, E.; Leite, J.; Viseu, C. Environmental behavior among higher education students. In Proceedings of the World 5th International Conference on Environmental Pollution, Treatment and Protection, Lisbon, Portugal, 18-20 October 2020; ICEPTP: Orléans, ON, Canada, 2020; pp. 155-1-155-2.

22. Qin, X.; Shen, Y.; Li, Z. 2011 Comparative study on environmental protection issues in integrated transport network planning of united states, Germany, and china. In Proceedings of the 11th International Conference of Chinese Transportation Professionals, Nanjing, China, 14-17 August 2011; American Society of Civil Engineers: Reston, VA, USA; pp. 2661-2672.

23. Gao, Z.; Wang, S.; Gu, J. Public participation in smart-city governance: A qualitative content analysis of public comments in urban China. Sustainability 2020, 12, 8605. [CrossRef] 
24. Mundorf, N.; Redding, C.A.; Paiva, A.L. Sustainable Transportation Attitudes and Health Behavior Change: Evaluation of a Brief Stage-Targeted Video Intervention. Int. J. Environ. Res. Public Health 2018, 15, 150. [CrossRef]

25. Nemoto, E.H.; Issaoui, R.; Korbee, D.; Jaroudi, I.; Fournier, G. How to measure the impacts of shared automated electric vehicles on urban mobility. Transp. Res. Part D Transp. Environ. 2021, 93, 102766. [CrossRef]

26. Castillo Esparcia, A.; López Gómez, S. Public opinion about climate change in united states, partisan view and media coverage of the 2019 united nations climate change conference (COP 25) in Madrid. Sustainability 2021, 13, 3926. [CrossRef]

27. Ghosh, S.; Das Chatterjee, N.; Dinda, S. Urban ecological security assessment and forecasting using integrated DEMATEL-ANP and CA-Markov models: A case study on Kolkata metropolitan area, India. Sustain. Cities Soc. 2021, 68, 102773. [CrossRef]

28. Połom, M.; Wiśniewski, P. Implementing electromobility in public transport in poland in 1990-2020. A review of experiences and evaluation of the current development directions. Sustainability 2021, 13, 4009. [CrossRef]

29. Teziev, T.M.; Beriev, O.G.; Samrailova, E.K.; Cidaev, B.S.; Savkhalova, S.C. Ecological and economic aspects of negative impact of transport in large cities. IOP Conf. Ser. Mater. Sci. Eng. 2019, 663, 012053. [CrossRef]

30. Valerio, F.; Basile, M.; Balestrieri, R. The identification of wildlife-vehicle collision hotspots: Citizen science reveals spatial and temporal patterns. Ecol. Process. 2021, 10, 6. [CrossRef]

31. Xing, C.; Ding, Y. Research on urban eco-environmental problems and sustainable development. IOP Conf. Ser. Earth Environ. Sci. 2019, 568, 012014. [CrossRef]

32. Vélez, A.M.A.; Plepys, A. Carsharing as a strategy to address GHG emissions in the transport system: Evaluation of effects of car sharing in Amsterdam. Sustainability 2021, 13, 2418. [CrossRef]

33. Macioszek, E.; Kurek, A. P\&R parking and bike-sharing system as solutions supporting transport accessibility of the city. Transp. Probl. 2020, 15, 275-286. [CrossRef]

34. Sidorchuk, R.; Mkhitaryan, V.S.; Skorobogatykh, I.I.; Stukalova, A.A.; Lukina, V.A. Modeling of the need for parking space in the districts of Moscow metropolis by using multivariate methods. J. Appl. Eng. Sci. 2020, 18, 26-39. [CrossRef]

35. Jairo, O.; Tóth, J.; Péter, T. A Comprehensive Model to Study the Dynamic Accessibility of the Park \& Ride System. Sustainability 2021, 13, 4064. [CrossRef]

36. Macioszek, E.; Kurek, A. The Use of a Park and Ride System-A Case Study Based on the City of Cracow (Poland). Energies 2020, 13, 3473. [CrossRef]

37. Dennis, K.; Lukas, R.; Thomas, B. Citizen preferences on private-public co-regulation in environmental governance: Evidence from Switzerland. Glob. Environ. Chang. 2021, 68, 102226.

38. Krukle, Z.; Biezina, L.; Ernsteins, R. Sustainable urban mobility planning development preconditions: Governance system approach. Pap. Presented Eng. Rural Dev. 2019, 18, 954-963.

39. Lai, W.; Chen, C. Behavioral intentions of public transit passengers-the roles of service quality, perceived value, satisfaction and involvement. Transp. Policy 2011, 18, 318-325. [CrossRef]

40. Lee, J. Setting the governance of a participatory ecosystem service assessment based on text mining the language of stakeholders' opinions. J. Environ. Manag. 2021, 284, 112003. [CrossRef] [PubMed]

41. Molina-Gómez, N.I.; Díaz-Arévalo, J.L.; López-Jiménez, P.A. Air quality and urban sustainable development: The application of machine learning tools. Int. J. Environ. Sci. Technol. 2021, 18, 1029-1046. [CrossRef]

42. Müller-Eie, D.; Bjørnø, L. The implementation of urban sustainability strategies: Theoretical and methodological implications for researching behaviour change. Int. J. Sustain. Dev. Plan. 2017, 12, 894-907. [CrossRef]

43. Ni, A.; Zhang, C.; Hu, Y.; Lu, W.; Li, H. Influence mechanism of the corporate image on passenger satisfaction with public transport in China. Transp. Policy 2020, 94, 54-65. [CrossRef]

44. Sztangret, I. Systemic sustainable development in the transport service sector. Sustainability 2020, 12, 9525. [CrossRef]

45. Myeong, S.; Jung, Y.; Lee, E. A study on determinant factors in smart city development: An analytic hierarchy process analysis. Sustainability 2018, 10, 2606. [CrossRef]

46. Viale Pereira, G.; Cunha, M.A.; Lampoltshammer, T.J.; Parycek, P.; Testa, M.G. Increasing collaboration and participation in smart city governance: A cross-case analysis of smart city initiatives. Inf. Technol. Dev. 2017, 23, 526-553. [CrossRef]

47. Zhang, H.; Song, J.; Su, C.; He, M. Human attitudes in environmental management: Fuzzy Cognitive Maps and policy option simulations analysis for a coal-mine ecosystem in China. J. Environ. Manag. 2013, 115, 227-234. [CrossRef]

48. Ullah, A.; Zhang, Q.; Ahmed, M. The impact of smart connectivity features on customer engagement in electric vehicles. Sustain. Prod. Consum. 2021, 26, 203-212. [CrossRef]

49. Ke, X.; Wang, X.; Guo, H.; Yang, C.; Zhou, Q.; Mougharbel, A. Urban ecological security evaluation and spatial correlation research-based on data analysis of 16 cities in Hubei province of China. J. Clean. Prod. 2021, 311, 127613. [CrossRef]

50. Tan, H.H. Environmental education for the sustainable development of suburban communities in Ho Chi Minh city. E3S Web Conf. 2021, 234, 00057.

51. Tao, J.; Zhou, Z. Evaluation of potential contribution of dockless bike-sharing service to sustainable and efficient urban mobility in China. Sustain. Prod. Consum. 2021, 27, 921-932. [CrossRef]

52. Xia, T.; Zhang, Y.; Braunack-Mayer, A.; Crabb, S. Public attitudes toward encouraging sustainable transportation: An Australian case study. Int. J. Sustain. Transp. 2017, 11, 593-601. [CrossRef]

53. Al-Thawadi, F.E.; Banawi, A.A.; Al-Ghamdi, S.G. Social impact assessment towards sustainable urban mobility in Qatar: Understanding behavioral change triggers. Transp. Res. Interdiscip. Perspect. 2021, 9, 100295. 
54. Alauddin, M.A.; Putri, A.K.; Abdurrahim, A.Y.; Pribandono, A.A.; Andriano, L.D.; Kurniawati, D.; Masruroh, B. Ecological damage and individualistic behavior: A study on the urban crisis in Surakarta city. IOP Conf. Ser. Earth Environ. Sci. 2021, 716, 012129. [CrossRef]

55. Azevedo, G.A.; Sampaio, R.R.; Filho, A.S.N.; Moret, M.A.; Murari, T.B. Sustainable urban mobility analysis for elderly and disabled people in sãopaulo. Sci. Rep. 2021, 11, 791. [CrossRef] [PubMed]

56. Okraszewska, R.; Romanowska, A.; Wołek, M.; Oskarbski, J.; Birr, K.; Jamroz, K. Integration of a Multilevel Transport System Model into Sustainable Urban Mobility Planning. Sustainability 2018, 10, 479. [CrossRef]

57. Oltra, C.; Sala, R.; Boso, À.; Asensio, S.L. Public engagement on urban air pollution: An exploratory study of two interventions. Environ. Monit. Assess. 2017, 189, 296. [CrossRef] [PubMed]

58. Reames, T.G.; Bravo, M.A. People, place and pollution: Investigating relationships between air quality perceptions, health concerns, exposure, and individual- and area-level characteristics. Environ. Int. 2019, 122, 244-255. [CrossRef]

59. Susilo, Y.O.; Williams, K.; Lindsay, M.; Dair, C. The influence of individuals' environmental attitudes and urban design features on their travel patterns in sustainable neighborhoods in the UK. Transp. Res. Part D Transp. Environ. 2012, 17, 190-200. [CrossRef]

60. Bi, J.; Zhang, Y.; Zhang, B. Public perception of environmental issues across socioeconomic characteristics: A survey study in Wujin, China. Front. Environ. Sci. Eng. China 2010, 4, 361-372. [CrossRef]

61. Chen, S.; Xu, D.; Jiang, W. High value passenger identification research based on federated learning. In Proceedings of the 12th International Conference on Intelligent Human-Machine Systems and Cybernetics, Hangzhou, China, 22-23 August 2020; IEEE: Piscataway, NJ, USA, 2020; pp. 107-110.

62. Lukina, A.V. The mechanism of green marketing for ecological ideas promotion in a region. Russ. J. Manag. 2017, 5, 615-624. [CrossRef]

63. Magdolen, M.; von Behren, S.; Burger, L.; Chlond, B. Mobility styles and car ownership—Potentials for a sustainable urban transport. Sustainability 2021, 13, 2968. [CrossRef]

64. Van, H.T. A cross Asian country analysis in attitudes toward car and public transport. In Proceedings of the 11th International Conference of Hong Kong Society for Transportation Studies, Hong Kong, China, 9-11 December 2006; Hong Kong Society for Transportation Studies: Hong Kong, China, 2006.

65. Van, H.T.; Fujii, S. A cross Asian country analysis in attitudes toward car and public transport. J. East. Asia Soc. Transp. Stud. 2011, 9, 411-421. [CrossRef]

66. Garcia-Sierra, M.; van den Bergh, J.C.J.M. Policy mix to reduce greenhouse gas emissions of commuting: A study for Barcelona, Spain. Travel Behav. Soc. 2014, 1, 113-126. [CrossRef]

67. Sidorchuk, R. The concept of "value" in the theory of marketing. Asian Soc. Sci. 2015, 11, 320-325. [CrossRef]

68. Schwartz, S.H. Universals in the content and structure of values. Adv. Exp. Soc. Psychol. 1992, 25, 1-65. [CrossRef]

69. Schwartz, S.H. An Overview of the Schwartz Theory of Basic Values. Online Read. Psychol. Cult. 2012, 2. [CrossRef]

70. Rokeach, M. The Nature of Human Values; Free Press: New York, NY, USA, 1973.

71. Lin, Y.; Chen, X.; Huang, L.; Zhu, C.; Shahtahmassebi, A.; Zhang, J.; Shen, S.; Peng, R.; Deng, J.; Wang, K.; et al. Fine-scale mapping of urban ecosystem service demand in a metropolitan context: A population-income-environmental perspective. Sci. Total Environ. 2021, 781, 146784. [CrossRef]

72. von Behren, S.; Schubert, R.; Chlond, B. International comparison of psychological factors and their influence on travel behavior in hybrid cities. Res. Transp. Bus. Manag. 2020, 36, 100497. [CrossRef]

73. Wang, X.; Yan, X.; Zhao, X.; Cao, Z. Identifying latent shared mobility preference segments in low-income communities: Ride-hailing, fixed-route bus, and mobility-on-demand transit. Travel Behav. Soc. 2022, 26, 134-142. [CrossRef]

74. Vecchio, G.; Castillo, B.; Steiniger, S. Urban mobility and elderlies in Santiago de Chile: The value of integrating analytical methods, a case study of the San Eugenio neighbourhood. Rev. Urban. 2021, 43, 26-45.

75. Suchanek, M.; Szmelter-Jarosz, A. Environmental aspects of generation Y's sustainable mobility. Sustainability 2019, 11, 3204. [CrossRef]

76. Xenias, D.; Whitmarsh, L. Dimensions and determinants of expert and public attitudes to sustainable transport policies and technologies. Transp. Res. Part A Policy Pract. 2013, 48, 75-85. [CrossRef]

77. Li, C.; Bai, L.; Liu, W.; Yao, L.; Travis Waller, S. Urban mobility analytics: A deep spatial-temporal product neural network for traveler attributes inference. Transp. Res. Part C Emerg. Technol. 2021, 124, 102921. [CrossRef]

78. Weiand, L.; Schmitz, S.; Becker, S.; Niehoff, N.; Schwartzbach, F.; Von Schneidemesser, E. Erratum: Climate change and air pollution: The connection between traffic intervention policies and public acceptance in a local context. Environ. Res. Lett. 2019, 14, 085008. [CrossRef]

79. Anable, J. 'Complacent car addicts'; or 'aspiring environmentalists'? Identifying travel behaviour segments using attitude theory. Transp. Policy 2005, 12, 65-78. [CrossRef]

80. Haan, M.; Konijn, E.A.; Burgers, C.; Eden, A.; Brugman, B.C.; Verheggen, P.P. Identifying sustainable population segments using a multi-domain questionnaire: A five-factor sustainability scale. Soc. Mark. Q. 2018, 24, 264-280. [CrossRef] [PubMed]

81. Kłos, M.J.; Sierpiński, G. Building a model of integration of urban sharing and public transport services. Sustainability 2021, 13, 3086. [CrossRef]

82. de Oña, J. Service quality, satisfaction and behavioral intentions towards public transport from the point of view of private vehicle users. Transportation 2021. [CrossRef] 
83. Breuer, D.; Spichartz, P.; Sourkounis, C. Concept of interlinking mobility services for urban transport towards intermodal mobility including private and shared electromobility. In Proceedings of the 2019 14th International Conference on Ecological Vehicles and Renewable Energies, Monte-Carlo, Monaco, 8-10 May 2019; IEEE: Piscataway, NJ, USA, 2019.

84. Hasan, M.H.; Van Hentenryck, P. The benefits of autonomous vehicles for community-based trip sharing. Transp. Res. Part C Emerg. Technol. 2021, 124, 102929. [CrossRef]

85. Alkharabsheh, A.; Moslem, S.; Oubahman, L.; Duleba, S. An integrated approach of multi-criteria decision-making and grey theory for evaluating urban public transportation systems. Sustainability 2021, 13, 2740. [CrossRef]

86. Chan, W.C.; Ibrahim, W.H.W.; Lo, M.C.; Suaidi, M.K.; Ha, S.T. Sustainability of public transportation: An examination of user behavior to real-time GPS tracking application. Sustainability 2020, 12, 9541. [CrossRef]

87. HeykenSoares, P.; Ahmed, L.; Mao, Y.; Mumford, C.L. Public transport network optimisation in PTV visum using selection hyper-heuristics. Public Transp. 2021, 13, 163-196. [CrossRef]

88. McCombs, M. The agenda-setting role of the mass media in the shaping of public opinion. In Proceedings of the Mass Media Economics 2002 Conference, London, UK, June 2002; School of Economics: London, UK, 2002.

89. Marans, R.W. Understanding environmental quality through the quality of life studies: The 2001 DAS and its use of subjective and objective indicators. Landsc. Urban Plan. 2003, 65, 73-83. [CrossRef]

90. Eboli, L.; Mazzulla, G. Performance indicators for an objective measure of public transport service quality. Trasp. Eur. 2012, 51, $1-21$.

91. Schwartz, S.H. Are there universal aspects in the structure and contents of human values? J. Soc. Issues 1994, 50, 19-46. [CrossRef]

92. Sidorchuk, R.R.; Efimova, D.M.; Skorobogatykh, I.I.; Meshkov, A.A.; Danchenok, L.A. Conceptual aspects of studying value reference points and consumer preferences of young consumers. Int. J. Appl. Bus. Econ. Res. 2016, 14, 7341-7360.

93. Sidorchuk, R. Study of the relationship between value orientations and consumer preferences of young consumers in Russia. J. Appl. Econ. Sci. 2017, 12, 2012-2027.

94. Sidorchuk, R.; Meshkov, A.; Musatov, B.; Skorobogatykh, I.; Efimova, D. Indication of the influence of motivational significance of values underlying young consumers' preferences for basic consumer products. J. Appl. Econ. Sci. 2018, 13, 150-163.

95. Department of Nature Use and Environment security in Moscow. Report on Moscow Environment Condition in 2020; Government of Moscow: Moscow, Russia, 2021. 